\title{
Observations on the ichnospecies Monomorphichnus multilineatus from the Nagaur Sandstone (Cambrian Series 2-Stage 4), Marwar Supergroup, India
}

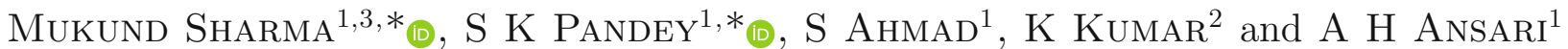 \\ ${ }^{1}$ Birbal Sahni Institute of Palaeosciences, 53 University Road, Lucknow 226 007, India. \\ ${ }^{2}$ Bond Business School, Bond University, Gold Coast, Queensland 4229, Australia. \\ ${ }^{3}$ Present address: Department of Geology, Banaras Hindu University, Varanasi 221 005, India. \\ *Corresponding author.e-mail: mukund_sharma@bsip.res.in,sangeology@yahoo.co.in
}

MS received 8 April 2017; revised 7 November 2017; accepted 7 November 2017; published online 10 July 2018

The Ediacaran-Cambrian Marwar Supergroup exposed in the western Rajasthan, India yielded abundant sigmoidal scratches assigned to ichnospecies Monomorphichnus multilineatus from the Nagaur Sandstone belonging to the Cambrian (Series 2-Stage 4). Nagaur M. multilineatus are recorded from the intertidal regime. It is an addition to already known depositional environments for this ichnospecies, which are known from shallow marine, wave-dominated, to non-marine or brackish water and storm-dominated sequences. Classical systematics of $M$. multilineatus is enriched with additional information in the paper. Its significance has been discussed regarding the palaeoecology of trace producers. Comprehensive statistical analyses help reveal its behaviour and feeding pattern of the causative organism of $M$. multilineatus. Hierarchical Cluster Analysis (HCA), average linkage and Pearson Correlation were performed to establish the natural grouping and behaviour of the specimens. HCA indicates that the studied Nagaur specimens belong to ichnogenera Monomorphicnus and ichnospecies, i.e., multilineatus. Pearson correlation, involving thickness and length of individual specimen, was positive. It indicates that the amount of food required by individual adult specimen was more and thereby requiring more grazing to provide enough food for survival. All the known occurrences of $M$. multilineatus are reviewed in the present study for their mode of preservation, depositional environment, palaeoecology and taphonomy.

Keywords. Monomorphichnus multilineatus; Kodymirus; Nagaur Sandstone; Marwar Supergroup; India.

\section{Introduction}

The Cambrian explosion is an exclusive evolutionary event of the appearance of most of the metazoan clades, which is rooted in the
Ediacaran Period (635-541 Myr), but in some instance, metazoan evolution is even considered to have initiated in still older successions belonging to the Cryogenian Period (720-635 Myr) (Weiguo et al. 1986; Gehling and Rigby 1996; Maloof et al.

Supplementary material pertaining to this article is available on the Journal of Earth System Science website (http://www. ias.ac.in/Journals/Journal_of_Earth_System_Science). 
2010; Sharma and Shukla 2012). Emergence of metazoans is, however, generally believed to have taken place in two consecutive successive stages. (1) During the Ediacaran Period when first multicellular animal clade came into existence and, (2) during the Cambrian Period when complex animals appeared in the form of arthropod including trilobite, Small Shelly Fauna (SSF) represented by ichnofossils and body fossils (Knoll and Carroll 1999; Erwin et al. 2011). The Nagaur Sandstone of the Marwar Supergroup, best exposed in western part of the peninsular India at Dulmera, Bikaner District, Rajasthan (figure 1a, b) represents one such Cambrian succession. In recent years, Nagaur Sandstone has revealed well preserved ichnofossils (Kumar and Pandey 2008, 2010; Sharma and Pandey 2011; Srivastava 2012a, b; Singh et al. 2013; Pandey et al. 2014; Ahmad and Kumar 2014). It may, therefore, be another window to study the second stage of metazoan evolution. The paper embodies the results of the detailed study on the ichnospecies Monomorphichnus multilineatus. Deep parallel dig marks with deeper central parts are diagnostic trait of this species. Their traces are noted in abundance on the red to maroon colour ferruginous siltstone/sandstone unit of the Nagaur Sandstone. Widely accepted as swimming/grazing traces, M. multilineatus was probably produced by the appendages of trilobite/arthropods, while floating into wave dominated shallow marine, non-marine, brackish water, and storm dominated deltaic environment of deposition from all over the globe (Alpert 1976; Fillion and Pickerill 1990; Mikuláš 1995; Mángano et al. 1996, 2005). Their significance has been discussed regarding feeding pattern as these are movement traces made in search of food in the water and sediment-water interface. Besides, present study compiles global distribution of genus Monomorphichnus, mode of preservation, size characteristics and its present occurrence in the intertidal depositional environments. The compilation brings out the abundance of $M$. multilineatus in the Cambrian succession with one exception in the Ordovician, while various other ichnospecies of Monomorphichnus are recorded up to the Cretaceous Period ( $\mathrm{Hu}$ and $\mathrm{Wu}$ 1993). It also shows that this is the second report of their occurrence from inter tidal regime (Tiwari and Parcha 2006). The taphonomic model presented the behaviour, activity, and habitats of extinct metazoans present during the deposition of the lower to middle Cambrian Nagaur Sandstone.

\section{General geology and age}

The Marwar Supergroup spreads over 51,000 km² area in the Jodhpur-Pali-Nagaur-BikanerJaisalmer districts in the western Rajasthan, India (figure 1a). The succession is present in the form of small hillocks and escarpments in a plain desert setting with limited exposures (Paliwal 2007). The Marwar Supergroup is more than 1000-m thick sedimentary succession (Pareek 1984). The litho-succession of the Marwar Supergroup is constituted of conglomerate, sandstones, shales, carbonates and evaporites. It is broadly subdivided into three groups, viz., the Jodhpur Group, the Bilara Group and the Nagaur Group in stratigraphical order (table 1). Both the Jodhpur and the Nagaur Groups are argillo-arenaceous units, while the Bilara Group is a calcareous succession. The Jodhpur Group is further subdivided into three units: the Pokaran Boulder Bed, the Sonia Sandstone, and the Girbhakar Sandstone. The Pokaran Boulder Bed is about 4-m thick unit, which overlies the Malani Igneous Suite (MIS) in the Pokaran area, whereas Sonia Sandstone overlies the MIS directly in rest of the basin. Overlying Bilara Group is subdivided into the Dhanapa Dolomite, the Gotan Limestone, and the Pondlo Dolomite. Cyclic sequences of evaporites have been observed in the subsurface drilling profile in the North Western part of the basin, which has been designated as the Hanseran Group (Kumar et al. 2005). Coeval phosphatic units are exposed in the western part of the basin (Birmania area, Barmer District), which is considered homotaxial succession of the Bilara Group (Srikantan et al. 1969; Chauhan and Bhanwara 1999; Hughes et al. 2015). The Nagaur Group represents the topmost unit of the Marwar Supergroup, which is subdivided into the fossil-bearing Nagaur Sandstone and the overlying Tunklian Sandstone. Depositional sedimentary structures are excellently preserved in all the groups.

In the Dulmera area, about 18-m thick succession of the Nagaur Sandstone is exposed in the open cast quarry from where the sandstone is extracted as building stone (figure $1 \mathrm{a}-\mathrm{c}$ ). Bedding planes are more or less horizontal and represented by sandstone with intercalating siltstones-shales with white to buff coloured laminae of muddrapes. Brick coloured fine to medium grained sandstone constitutes the dominant lithology. The brown mudstone and red shales with few streaks of green shales are also seen. At certain places, 


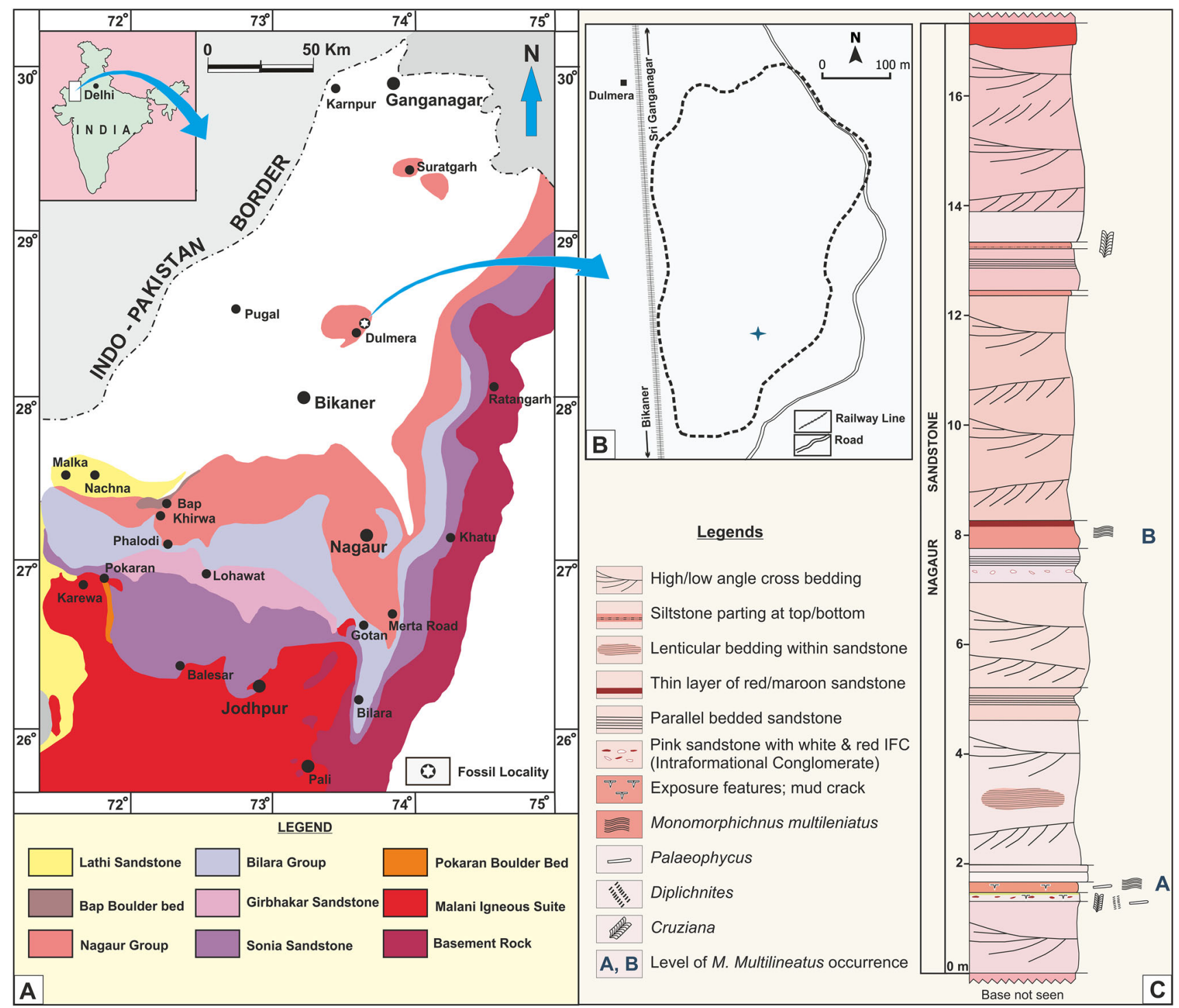

Figure 1. Geological map of the study area and litholog of the Monomorphichnus multilineatus bearing succession. (a) Geological map of the Marwar Supergroup, western Rajasthan, showing fossil locality exposed in Dulmera village (after Pareek 1984). (b) The geographical extent of the Dulmera quarry along the Dulmera Railway station. (c) Generalised litholog of the Nagaur Sandstone succession bearing M. multilineatus.

mauve coloured medium grained sandstone has also been noted. Large and small scale cross beddings, massive bedding and parallel beddings along with tidal bundles are the dominant sedimentary features. Wave ripple marks and mud cracks are also seen. Mud gals in the sandstones are quite common.

The entire Marwar Supergroup succession unconformably overlies the Malani Igneous Suite which has been dated around $771 \pm 5$ Ma by $\mathrm{U}-\mathrm{Pb}$ dating (Gregory et al. 2009) and is unconformably overlain by the Permo-Carboniferous Bap Boulder Beds. Tuff occurring within the Jodhpur Group in the Chhoti Khatu area yielded $\mathrm{Rb}-\mathrm{Sr}$ whole-rock isochron of $703 \pm 40 \mathrm{Ma}$ (George and Ray 2017). Sr isotope stratigraphy suggests a depositional age of $\sim 570 \mathrm{Ma}$ (late Ediacaran) for the Bilara Group indicating a depositional hiatus of 100 Ma between the Jodhpur and Bilara Group (George and Ray 2017).

LA-ICP-MS DZ study of Nagaur Group also supports the lower Cambrian age, i.e., $\sim 540 \mathrm{Ma}$ for the Nagaur Sandstone (McKenzie et al. 2011). Torsvik et al. (2001), van Lente et al. (2009) and Meert et al. (2013) suggested the age of intrusive MIS between 770 and 750 Ma. It implies that the Marwar Supergroup sediments are neither older than 771 Ma nor younger than the Cambrian. On the basis of negative shift of $\delta^{13} \mathrm{C}$, Pandit et al. (2001), Mazumdar and Bhattacharya 
Table 1. Generalized stratigraphic succession of the Marwar Supergroup (after Pareek 1984; Chauhan et al. 2004).

\begin{tabular}{|c|c|c|c|c|}
\hline Age & Supergroup & Group & Formation & Lithology \\
\hline \multirow[t]{4}{*}{ Permo-Carb. } & & & Bap Boulder Bed & Subrounded, ellipsoidal cobbles and pebbles \\
\hline & & & Unc & formity \\
\hline & & $\begin{array}{l}\text { Nagaur Group } \\
(75-500 \mathrm{~m})\end{array}$ & Tunklian Sandstone & Brick red sandstone, siltstone \& red claystone \\
\hline & & $\begin{array}{l}<540 \mathrm{Ma}(\mathrm{DZ} \\
\text { LAICPMS })\end{array}$ & Nagaur Sandstone & $\begin{array}{c}\text { Brick red sandstone, siltstone \& red and } \\
\text { green clay beds }\end{array}$ \\
\hline \multirow[t]{6}{*}{$\begin{array}{l}\text { Ediacaran } \\
\text { to Middle } \\
\text { Cambrian }\end{array}$} & $\begin{array}{c}\text { Marwar } \\
\text { Supergroup }\end{array}$ & $\begin{array}{l}\text { Bilara Group } \\
(100-300 \mathrm{~m})\end{array}$ & Pondlo Dolomite & $\begin{array}{c}\text { Cherty dolomitic limestone, siliceous oolites } \\
\text { and pesolites with subordinate claystone, } \\
\text { siltstone at places }\end{array}$ \\
\hline & & & Gotan Limestone & $\begin{array}{l}\text { Dark grey laminated limestone with bands of } \\
\text { clay, chert and dolomite }\end{array}$ \\
\hline & & & Dhanapa Dolomite & $\begin{array}{c}\text { Stromatolitic limestone, dolomite, siliceous } \\
\text { dolomitic limestone and laminated and } \\
\text { nodular chert at the base }\end{array}$ \\
\hline & & & Girbhakar Sandstone & $\begin{array}{l}\text { Brick-red sandstone, siltstone and shale, } \\
\text { pebbly to gritty near top }\end{array}$ \\
\hline & & $\begin{array}{l}\text { Jodhpur Group } \\
(125-240 \mathrm{~m})\end{array}$ & Sonia Sandstone & $\begin{array}{l}\text { Maroon siltstone and shale, creamish sand- } \\
\text { stone with sedimentary structures. Banded } \\
\text { chert-jasper, subordinate dolomite and } \\
\text { sandstone }\end{array}$ \\
\hline & & & Pokaran Boulder Bed & $\begin{array}{c}\text { Sub-rounded, ellipsoidal cobbles, pebbles } \\
\text { and sandstone }\end{array}$ \\
\hline \multicolumn{2}{|l|}{ 779-681 Ma } & \multicolumn{3}{|c|}{ Malani Igneous Suite } \\
\hline
\end{tabular}

(2004), Mazumdar and Strauss (2006) and Ansari et al. (2018) proposed the Precambrian-Cambrian boundary within the Bilara Carbonate. A study based on acritarch assemblage (Prasad et al. 2010) suggested late Ediacaran to early late Cambrian age (ca. 570-500 Myr) for the Bilara Group of the Marwar Supergroup however, Hughes (2016) did not agree with this assignment. Therefore, the Bilara Group sediments are considered to have deposited between 570 and 540 Myr. Apart from these stable isotope signatures, palaeomagnetic data also suggest that the sediment of the basin started depositing around 748 Ma (Torsvik et al. 2001). Recently, Davis et al. (2014) synthesised all the geochronological ages with palaeomagnetic data and inferred the deposition of these sediments of the Marwar Supergroup between 570 and 521 Ma. So far no body fossil has been reported from the Nagaur Sandstone.

\section{Previous studies}

While mapping the surface extent of rocks of the Marwar Supergroup, a few passing notes were made by the geologists of the Geological Survey of India and some other researchers on the fossil contents of the rocks of various groups (Khilnani 1964, 1968; Khan 1973; Barman 1980, 1987; Maithy 1984). Concerted efforts were made in the last decade to document the palaeobiological remains from different groups of the Marwar Supergroup. From the Jodhpur Group, the lower most unit of the Marwar Supergroup, a number of fossil remains belonging to metaphytic and metazoan affinities and others designated as Microbially Induced Sedimentary Structures (MISS) were recorded or restudied or reinterpreted (Raghav et al. 2005; Sarkar et al. 2008; Kumar and Pandey 2009; Kumar et al. 2009; Samanta et al. 2011; Kumar and Ahmad 2012a, b, 2014, 2016; Parihar et al. 2012; Srivastava 2012c, 2014; Sarkar et al. 2014; Pandey and Sharma 2017). Palaeobiological studies on the Bilara Group sediments, the middle unit of the Marwar Supergroup, yielded palynological remains belonging to cyanobacteria and acritarchs (Mehrotra et al. 2008; Babu et al. 2009). These records, however, need restudy to address the issues of contamination and syngenecity of the reported microbial remains. In a 
separate study based on bore cores, Prasad et al. (2010) recorded Ediacaran lower Cambrian palynoassemblage (ca. 570-500 Myr) from the Bilara Group of the Marwar Supergroup, but Hughes (2016) considered this assignment unwarranted and suggested that the Bilara Group sediments to have deposited between 570 and 540 Myr. Therefore, the underlying Jodhpur Group of the Marwar Supergroup must be older than $570 \mathrm{Ma}$ or younger than $681 \mathrm{Ma}$ and the Nagaur Sandstone must be younger than 540 Ma. Following Kumar and Pandey (2008, 2010), there has been a great surge in reporting of trace fossils, scratch marks and burrows produced by the trilobite and other arthropods from the Nagaur Sandstone of the Nagaur Group exposed in the Dulmera area, Bikaner District, western Rajasthan. Singh et al. (2013) claimed to have recorded redlichid trilobite and compared the specimen with articulated arthropod tergites. Poor photo-documentation and solitary specimen makes this record rather unconvincing. Srivastava (2012a, b) described Treptichnus pedum and priapulid worms from the Nagaur Sandstone and claimed the Pc-C boundary within the Nagaur Group. Recently, Sharma et al. (2018) presented a comprehensive study of around 291 in-situ specimens of the T. pedum on its morphological attributes, palaeoecology, mode of preservation, along with statistical analysis to infer the behaviour of the burrow-maker. Reviews on the trace fossils assemblage by Sharma and Pandey (2011), Singh et al. (2014) and Pandey et al. (2014) suggested that trace fossil hosting rocks belong to Stage 2 of the Cambrian Period (upper part of Terreneuvian). Contrary to these claims, Pandit et al. (2001), Maheshwari et al. (2003), Mazumdar and Bhattacharya (2004), Mazumdar and Strauss (2006), Pandey and Bahadur (2009) and Ansari et al. (2018) suggested that Pc-C boundary lies within the Bilara Group on the basis of chemostratigrahic data.

\section{Observations on the Nagaur Monomorphichnus multilineatus}

\subsection{Distribution of M. multilineatus}

Specimens of $M$. multilineatus were collected from the 18-m thick succession of the Nagaur Sandstone exposed in the quarry section of Dulmera village (figure 1c). Traces of $M$. multilineatus are noted at two levels in ferruginous sandstone facies. In the present study, a large number of specimens of this species are examined. M. multilineatus is preserved as grooves/hyporelief on the top of the bedding plane or as positive epirelief on the sole of the beds which is characterised by the numbers of parallel to sub-parallel ridges formed by the scratch marks. Other ichnogenera of the Dulmera assemblage, viz., Cruziana, Palaeophycus, Diplichnites are also reported from the same horizon, whereas, $T$. pedum has been reported from the overlying horizon. It is uncertain whether $T$. pedum represents FAD or not at this place.

\subsection{Petrographic characteristic of Nagaur Sandstone}

Two petrological slides of fossil-bearing Nagaur Sandstone have been prepared and studied under petrological microscope (figure 2). Grains are moderate to well sorted in nature with thin rim of iron-bearing mineral with minor carbonate cement. Quartz grains are anhedral to subhedral or sometime angular in shape with irregular boundaries. Quartz grains range between fine and medium size, coated with red haematite/iron-bearing mineral/brownish yellow colour limonite. Limonite is the predominant form of iron oxide, but there are also small quantities of hematite. The cement is limonite, but sometime it occurs as scattered patches or grains, and as coatings on the quartz particles, which makes grain boundary of quartz non-resistant to etching/weathering/abrasion/ erosion. Iron containing mineral acts as cementing material for binding these grains together. A very fine coating/rim of Iron Bearing Mineral (IBM) around the quartz grains can be seen under the microscope (figure $2 \mathrm{a}$ and $\mathrm{b}$ ). Very fine lamination can be noted under the microscope. Ferruginous nature of the Nagaur Sandstone indicates occurrence of iron and titanium oxide minerals which were responsible for the formation of authigenic iron-bearing mineral such as rutile, anatase, hematite, etc., in the Nagaur Sandstone. To determine the correct nature of iron-bearing mineral, we performed Raman Spectroscopic study on the Nagaur Sandstone petrographic thin section (figure 2c). The study revealed the presence of distinct spectral bands of 142, 199, 398, 518 and 641 , which indicate the presence of mineral anatase. It is a polymorph of rutile and brookite having the similar chemistry $\left(\mathrm{TiO}_{2}\right)$, but different crystal structures. Although it usually occurs in igneous and metamorphic rocks as a 

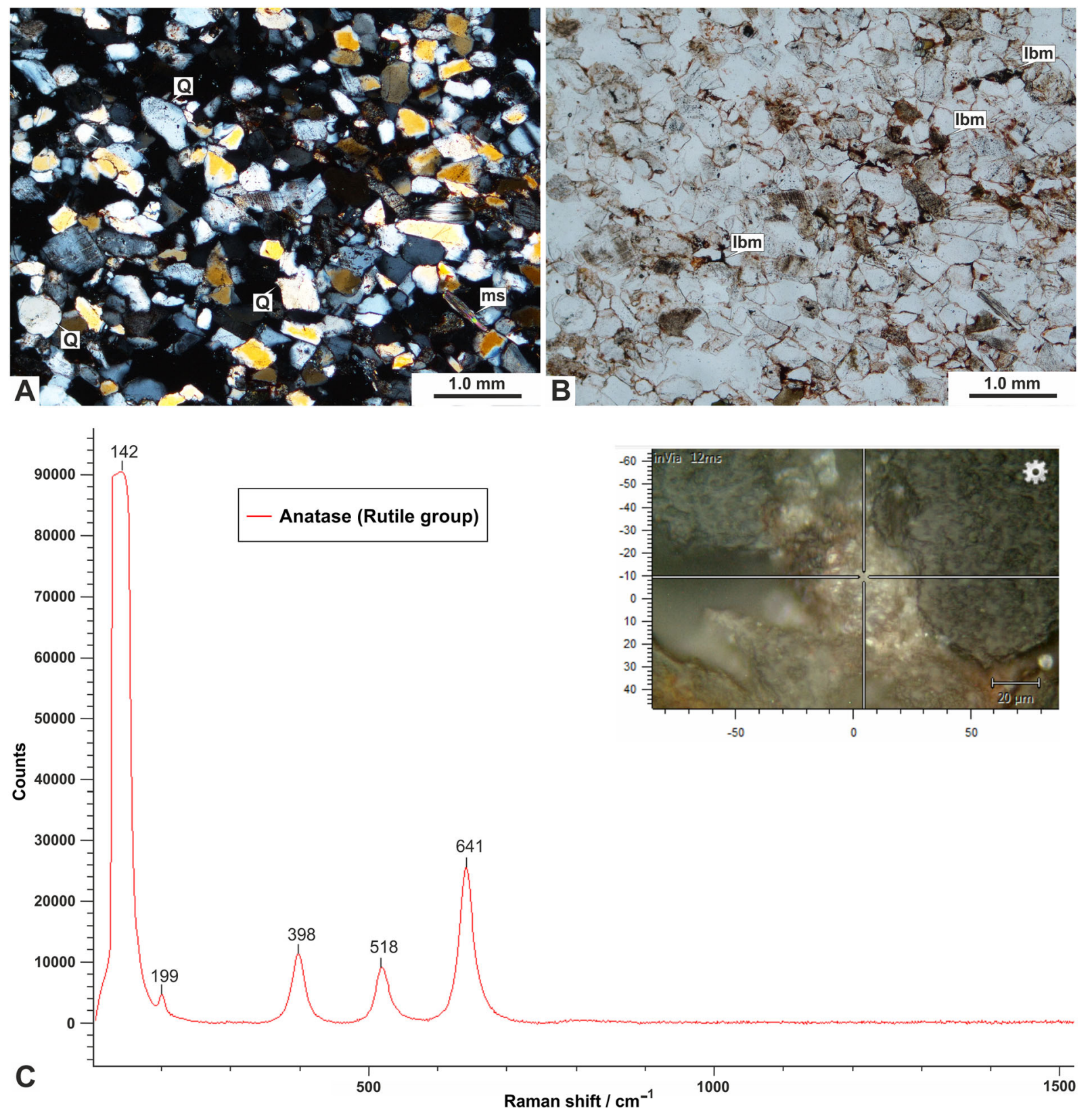

Figure 2. Photomicrograph of sandstone/ironstone containing M. multilineatus; $(\mathrm{Q}=\mathrm{Quartz}$; Ms = Muscovite; ibm = Iron bearing mineral). (a) Siltstone/sandstone shows subangular to subrounded detrital quartz grains along with muscovite flakes cemented by silica as well as iron containing mineral (Under cross nicol); (b) Photomicrograph of (a) (under plane polarised light). (c) Raman Spectra of mineral Anatase in the matrix of petrographic slide of Nagaur Sandstone BSIP-15261: spectral bands 142/199/398/518/641 indicate the presence of anatase in fossil bearing NS.

secondary product or derived from other Ti-bearing minerals like titanite $\left(\mathrm{CaTiSiO}_{5}\right)$, ilmenite $\left(\mathrm{FeTiO}_{3}\right)$, titanium magnetite $\left(\mathrm{Fe}_{3} \mathrm{O}_{4}\right)$, hematite $\left(\mathrm{Fe}_{2} \mathrm{O}_{3}\right)$, rutile, brookite and quartz, $\mathrm{TiO}_{2}$ represents highest oxidizing state of $\mathrm{Ti}$, it indicates a well-oxygenated depositional environment supporting the ferruginous nature of the Nagaur Sandstone, corroborating the evidence of aerobic environment. This evidence strongly suggests that the Nagaur Sandstone was deposited in a very well ventilated oxygenic environment.

\subsection{Depositional environment}

The Marwar Supergroup sediments overlie the Malani Igneous Suite (MIS-771 Ma) and at some places on the older metamorphic rocks (850$1000 \mathrm{Ma}$ ). Of the three divisions of the Marwar 
Supergroup, the Pokaran Boulder Bed constitutes the base of the lower-most Jodhpur Group which some researchers considered to have deposited by the glacio-fluvial activity (Bhatt et al. 2002; Chauhan et al. 2004). The other constituent rocks of Jodhpur Group are fine- to coarse-grained argillaceous, arenaceous and calcareous in nature representing marine to non-marine litho-package. However, the other three divisions of the Jodhpur Group are considered to have been deposited in deltaic, beach and fluvial environments (Chauhan and Bhanwara 1999). The Sonia Sandstone, overlying the Pokaran Boulder Bed, is composed of three different litho-facies: a coastal marine facies is sandwiched between two sub-aerial fluvial facies (Sarkar et al. 2005, 2008, 2012; Bose et al. 2012). The coastal facies consists of three sub-facies, viz., lower (a), middle (b) and upper (c). The upper and lower (a and c) facies represent wave-dominated shallow to deep neritic palaeoenvironmental conditions; where as the middle facies (b) is identified as a supra-littoral zone, representing the backshoreforeshore environment of deposition. The coastal facies consists of fine- to coarse-grained sandstone showing abundant development of wave and current ripple bedding, parallel bedding, large and small cross-bedding, interference ripples, adhesion ripples, starved ripples, rain prints, syneresis cracks and mud cracks. Intercalations of shaly siltstone are very thin and rare, but conspicuously present in this facies (Sarkar et al. 2005, 2008, 2012). Microbial mat structures are also reported from the Sonia Sandstone (Samanta et al. 2015).

Overlying Bilara Group is the result of chemically precipitated carbonate rocks deposited in tidal flat environment (Mazumdar and Strauss 2006). A thick limestone succession is noted in the Bilara Group bounded by the dolomites in the underlying and overlying formations. Lower part is predominantly stromatolitic, whereas middle part is constituted of large limestone mounds. The upper part is constituted of siliceous, pesolitic dolostone. Current ripple laminations along with tidal bundles are common sedimentary structures throughout Bilara succession (Mazumdar and Strauss 2006). Truncated ripple lamination is also commonly observed. Rare presence of mud-cracks in middle part suggests sub-aerial exposure in an arid environment. Parallel crinkled microbial laminites are profusely developed in the lower succession of Bilara carbonate. Well developed stromatolitic build-up is also noticed in the Dhanapa Dolomite with abundance of thin chert laminae.
Presence of these sedimentary structures suggests deposition in an intertidal zone (Reineck and Singh 1980). Shrivastava (2005) suggested intertidal to supratidal depositional environments for the Bilara Group on the basis of presence of stromatolite. Though, the abundance of stromatolites, parallel laminated carbonate sediments along with $\delta^{13} \mathrm{C}$ signatures, suggest that the Bilara carbonate deposited in shallow, low to moderately high energy marine water (Pandit et al. 2001; Maheshwari et al. 2003; Pandey and Bahadur 2009).

The upper-most Nagaur Group is constituted of brick-red sandstone, siltstone, and greenish clay with several primary sedimentary structures (ripples, low to high angle cross bedding, trough cross bedding, syneresis and mud cracks, etc.). It is subdivided into two formations: the Nagaur Sandstone and the Tunklian Sandstone. The Nagaur Sandstone is the basal unit and composed of fineto medium-grained brick-red sandstone and siltstone with blotches of green clay. The Tunklian Sandstone is comparatively coarser in nature, composed of brick-red sandstone, siltstone, claystone with gritty to pebbly sandstone at the top (Pareek 1984). Large and small scale cross bedding, massive bedding, parallel bedding, wave ripple, mud cracks and mud gals are the dominant sedimentary features. Depositional environment of the Nagaur Sandstone has been interpreted by several workers in diverse mode: Non-marine shallow water to marine (Shrivastava 1971, 2005); marine (Pareek 1984); low to high energy marine to marginal marine aerobic environment of deposition has been suggested for the Nagaur Group of rocks (Pandey and Bahadur 2009); intertidal sand-flat with channel setting (Pandey et al. 2014); subtidal environment of deposition (Singh et al. 2014). In general, deposition environment of the Nagaur Sandstone could be inferred just above fair weather wave base probably in the intertidal regime, whereas fossil bearing strata in upper intertidal shoal complex with periodic sub-aerial exposure during low tides.

The trace fossils $M$. multilineatus are encountered at two levels in the Dulmera quarry section. The first level is noted at about $2 \mathrm{~m}$ from the excavated base and second level is seen at $8 \mathrm{~m}$ in a vertically exposed section (figure 3a). Lower unit is $\sim 50 \mathrm{~cm}$ thick whereas upper level is comparatively thinner. The fossil bearing litho-facies is red to maroon in colour and characterised by medium to coarse grained sandstone unit intercalated with thin layer of mudstone unit as drapes and thin 
laminations (figure 3e and f). Mud cracks (figure 3b and c) and mud-chip conglomerate (figure 3f) are also noted in this litho-facies suggesting limited time period sub-aerial exposure during low tide in the low-lying trough regions. Rarely small scale ripple laminations are observed in sandy streak parts of the mudstone unit. Overlying and underlying sandstone units are brick coloured, thickly bedded along with large scale trough cross-bedding (figure 3d), planar cross-bedding and low to high-angle cross-beddings. Some of the planar cross-beddings show reactivation surfaces resembling tidal bundles (figure $3 \mathrm{~g}$ ). In some cases the bounding surfaces in the sandstone facies are undulatory indicating influence of waves (figure 3e). Shallow water wave dominated, aerobic marginal marine environment, above the fair-weather wave base in the intertidal regime, could be inferred as the habitat of trace producing organism in the Nagaur Sandstone. This litho-facies represents its deposition in low-lying interbar areas, which was protected from strong wave action and tidal currents and suitable for faunal activities. The set of sedimentary features suggest that the fossil bearing sandstone facies was deposited as intertidal sand shoal complex under the influence of tidal currents and wave actions.

\subsection{Taphonomy}

Post-mortem decay of organisms, their disintegration and subsequent incorporation as fossils in geological records is defined as taphonomy (Martin 1999). Taphonomic processes help understand the preservation of trace fossils in any settings. Though fossils provide considerable indication on the environmental factors, the information loss in the process of fossilization can only be gauged by the study of phenomenon operational at temporal scale (geological scale) (Behrensmeyer and Kidwell 1985). Sandstone and mudstone interfaces present in the Nagaur Sandstone provide most suitable media for preservation of $M$. multilineatus trace fossils. The scratch marks termed as M. multilineatus are peculiar in nature. Besides these scratch marks, the ichnofauna of Nagaur Sandstone is typical of a soft ground community (Ekdale et al. 1984). Detailed study of these marks shows distinct gooves/ridges, pattern and behaviour that help us understand the possible way of formation of these traces on the sediment. Several recorded M. multilineatus are found profusely in shallow marine environment and therefore, certain facts can be inferred regarding the causative organisms, circumstances in which they were formed and their mode of preservation. Monomorphichnus type parallel scratch marks are possibly produced by the elongated spines of an organism (enigmatic crustaceans/arthropod or trilobite) or by various modes of locomotion or by resting on the bottom near the sediment-water interface or during their movements by an organism such as $K$. vagans or by any unknown trace-marker (Mikuláš 1995). In Cambrian marginal marine realm, Kodymirus is considered to be the earliest known predator (Mikuláš 1995). K. vagans was possibly the early ancestral form of eurypterids which are known to have appeared during middle Ordovician (Fillion and Pickerill 1990) and therefore its comparison with $M$. multilineatus has a limiting factor for drawing any inference regarding the causative organism or pattern.

\section{Material and methods}

Present study is based on the field as well as laboratory observations. Manually operated Dulmera quarry has yielded $M$. multilineatus trace fossils reported in this paper (figure 1b). The quarry is situated close to Dulmera railway station in Bikaner District, Rajasthan. Fossil specimens, collected in-situ, were noted at the two different levels representing horizon - A and B of the bedding planes of the Nagaur Sandstone (figures 1c and 3a). All the relevant measurements on the trace fossils were made in the laboratory at BSIP. Raman Spectroscopy was performed on petrographic thin section (slide no. BSIP 15261) at Birbal Sahni Institute of Palaeosciences using a RENISHAW in via Reflex Raman Microscope that permits acquisition both of point spectra and of Raman images that display the two-dimensional spatial distribution of the molecular-structural components of the specimens and their associated mineral matrix. The microscope optics of the Raman system is based on a Leica DM-2700M REN RL/TL microscope. The instrument was calibrated against Raman signal for Si obtained from internal silicon wafer reference at $520 \mathrm{~cm}^{-1}$. Spectral acquisition was performed over a range from $\sim 100$ to $\sim 2000 \mathrm{~cm}^{-1}$. The samples were exposed to the coherent Argon Ion $\left(\mathrm{Ar}^{+}\right)$laser provided excitation at $451-\mathrm{nm}$ wavelength at a power of $\sim 1-5$ $\mathrm{mW}$ over an $1.5 \mu \mathrm{m}$ to obtain a good signal to noise ratio and to avoid the radiation damage 

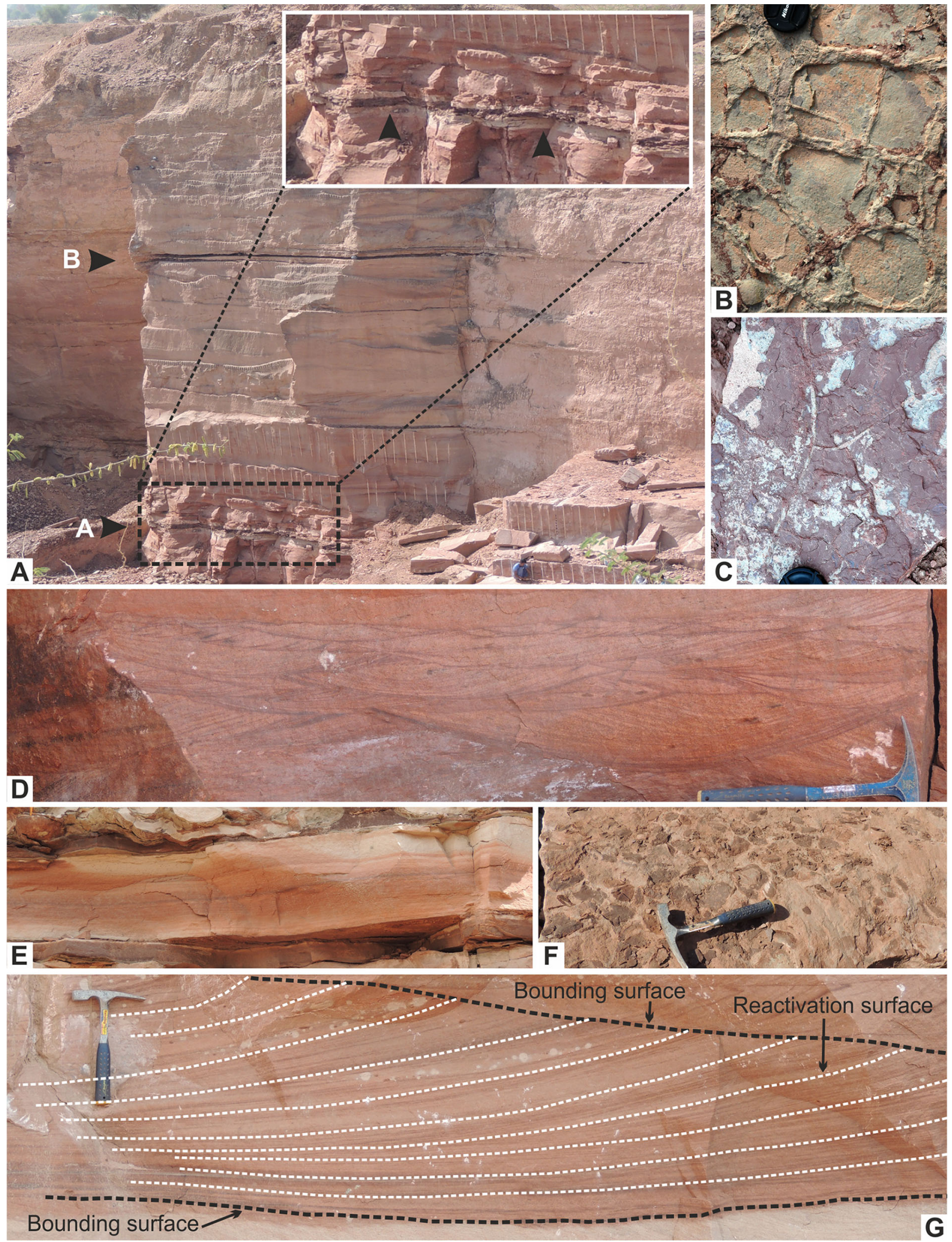

Figure 3. (a) 18 meters vertically exposed section of the Nagaur Sandstone showing two fossiliferous horizons 'A' and 'B': Enlarge view can be seen in upper right corner (black arrow shows the brick red coloured about $50 \mathrm{~cm}$ thick fossiliferous horizon); (b, c) Polygonal mud cracks exposed on top of the bedding plane; (d) Well developed trough cross bedding in vertical section of the Nagaur Sandstone; (e) Planner and undulated strata influenced by wave action between two interbar facies; (f) Probable tidal bundles with reactivation and bounding surfaces marked on sandstone in overlying unit of fossil strata. (scale: a: A man in sitting position in right lower corner; b, c: Lens cap diameter $=6.5 \mathrm{~cm}$; d, f, g: Hammer length $=30 \mathrm{~cm} ; \mathrm{e}=$ planner bed is about $30 \mathrm{~cm}$ thick). 
and minimize laser induced heating (following Schopf et al. 2005). In these conditions, the time of the analysis was for a few minutes (accumulated time of $30 \mathrm{~s}$ and 10 scans). A $50 \times$ objective lens (having an extended working distance of 10.6 $\mathrm{mm}$ and a numerical aperture of 0.5 ) was used so the horizontal spectral resolution of $1.5 \mu \mathrm{m}$. The collected spectral bands are 142, 199, 398, 518 and 641, which indicate presence of mineral anatase.

Twenty-two specimens (slabs) and two petrological thin sections are deposited in the repository of the museum of Birbal Sahni Institute of Palaeosciences (specimen No. BSIP 40430-40438 and slide Nos. BSIP 15261 and 15262; BSIP Statement No: 1458). Additional specimens, not photodocumented in the present paper, bear the No: BSIP 40439-40451 are also deposited in the repository. Obtained data for statistical analyses have been processed on the ORIGINSPRO 8 software.

\section{Systematic palaeontology}

Monomorphichnus Crimes, 1970

Monomorphichnus multilineatus Alpert, 1976

Monomorphichnus multilineatus (figures 4-6) (table 2)

Material: Twenty-two slabs of very fine to medium grained ferruginous sandstone and interspersed mudstone ironstone with specimens preserved as positive epirelief and hyporelief. Specimen No. BSIP 40430-40438; additional specimens BSIP 40439-40451; Slide No. BSIP 15261-15262.

Stratigraphic horizon: Monomorphichnus multilineatus occurs on the ferruginous sandstonemudstone unit of the Nagaur Sandstone, Nagaur Group, Marwar Supergroup.

Description: Four to twenty-two parallel, straight to sinuous grooves/ridges on top or bottom of the bedding plane. Ridges are sub-parallel with strong and deep relief or flattened. Ridges are wider and deeper in the central part than those of either side. However, some ridges converge or diverge from one point. In some cases, overlapping sets are also noted but such intersecting ridges are also parallel. Measurements on these sets are obtained for their length, thickness and distance (see figure 7). Length (L) of the ridges ranges from 04 to $32 \mathrm{~mm}$ while thickness $(\mathrm{T})$ from $0.2-1.5 \mathrm{~mm}$. Distance (D) between two ridges varies from 0.5 to $3.0 \mathrm{~mm}$.
Remarks: Alpert (1976) described the Monomorphichnus multilineatus as scratch mark probably produced by appendages of trilobite while in motion close to sediment water interface. Deep parallel dig marks and deeper central part is diagnostic feature for this species. However, Bergström (1973) and later on Alpert (1976) described it that it is presumably produced by powerful multi digitate appendages (the exites). In the Nagaur specimens, one set of ridge is produced by at least 22 lamellae as compared to 17 lamellae described by Bergström (1973). The present status of Monomorphichnus is presently thought to be a rare and controversial ichnogenus. Mángano and Buatois (2003) and Mángano et al. (2005) discussed its close affinity with another ichnogenus Dimorphichnus. Nagaur specimens have lower as well as higher number of scratch marks which is close to specimens described by Alpert (1976). It is, probably produced by the activity of Kodymirus or Kockuras (Mikuláš 1995). There are still some unresolved questions pertaining to the mode of occurrence, size and number of appendages of $M$. multilineatus forming organism. Citing personal communication with Prof. Seilacher, specimens similar to M. multilineatus have been repeatedly mentioned as Cruziana nabataeica, but we could not find any description or comparison of Cruziana nabataeica from Nagaur in print beyond the first cited in McKenzie et al. (2011), page 475 of which Sharma is also an author; and repeated by McKenzie (2012, page 19); Meert and Pandit (2015, page 33); and Hughes (2016, page 448). Inadvertently, the specific epithet which was wrongly cited as 'nabatacica' (McKenzie et al. 2011) for the Nagaur specimen continued in subsequent publications (McKenzie 2012; Meert and Pandit 2015; Hughes 2016). The type specimen of Cruziana nabataeica described from Wadi Siyagh, city of Petra, Jordan is small rusophyciform trilobite burrows of the fasciculate-group having 10 equally spaced blunt ridges (Seilacher 1990). Their occurrence is considered as a lower Cambrian in age. Specimens described by us as $M$. multilineatus are having sub-parallel, unequally placed ridges with strong and deep relief. Many of these ridges are wider and deeper in the central part than those of either side. Numbers are also lesser. Therefore, we prefer to retain the identification of these specimens as M. multilineatus.

Age: So far, M. multilineatus is well reported from the lower Cambrian up to lower Ordovician. Deep Spring Formation, USA; Paseky Shale, Czech Republic from the lower Cambrian (Alpert 1976; 


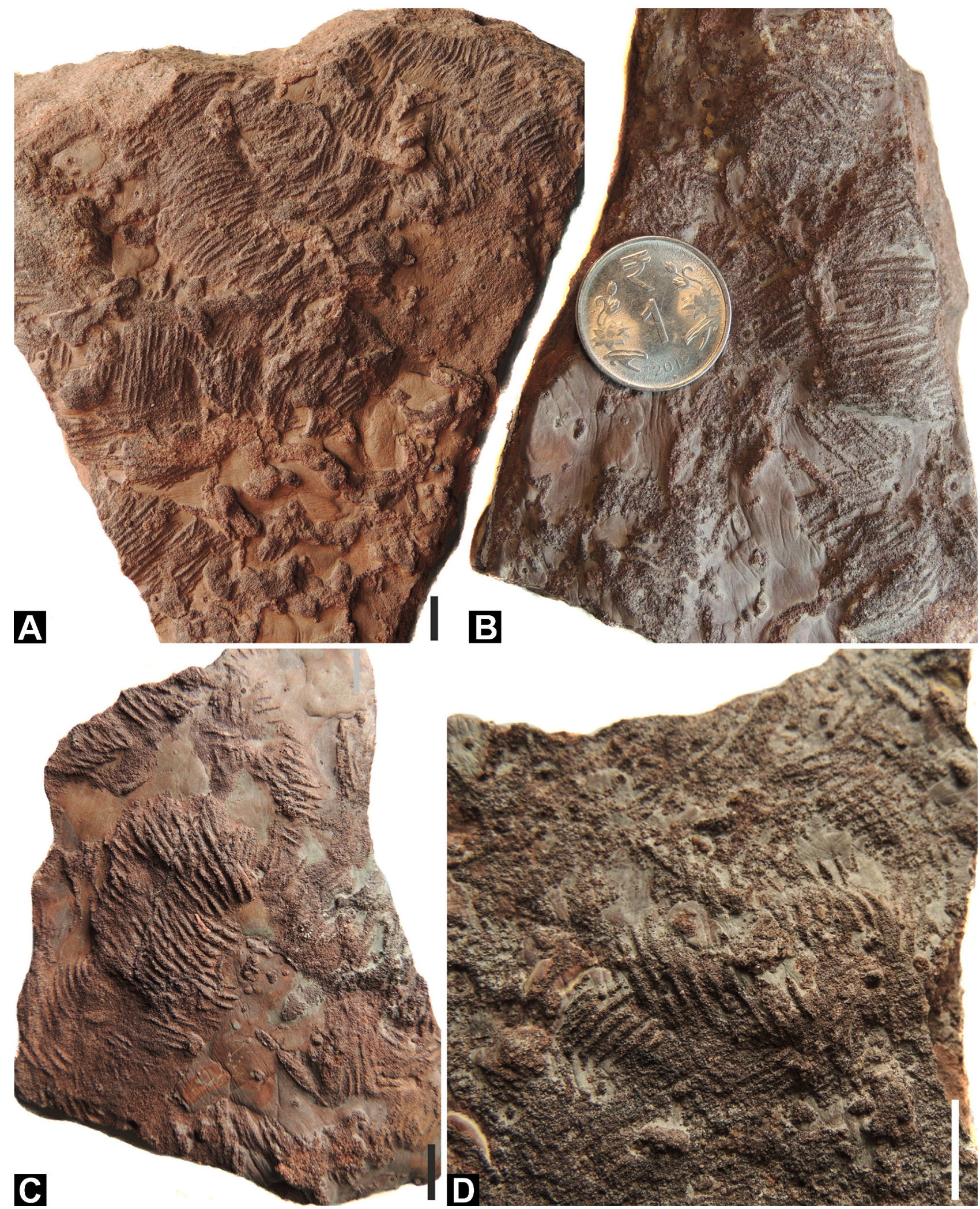

Figure 4. Showing Monomorphichnus multilineatus on the bedding plane of brick red to maroon coloured Nagaur Sandstone. (scale bar $=1.0 \mathrm{~cm}$ for a, c, d). (a) Sinuous pattern of long subparallel ridges indicate slow diving or locomotion of $K$. vagans near sediment water interface. (BSIP Specimen No. BSIP-40430). (b) Group of ridges showing different direction on the unstable bedding plane. (BSIP Specimen No: BSIP-40431). (c) Bunch of slight sinuous ridges on the bedding plane. (BSIP Specimen No: BSIP-40432). (d) Criss-cross pattern of ridges in different direction indicate the presence of probably two $K$. vagans near the sediment water interface. (BSIP Specimen No: BSIP-40433). 


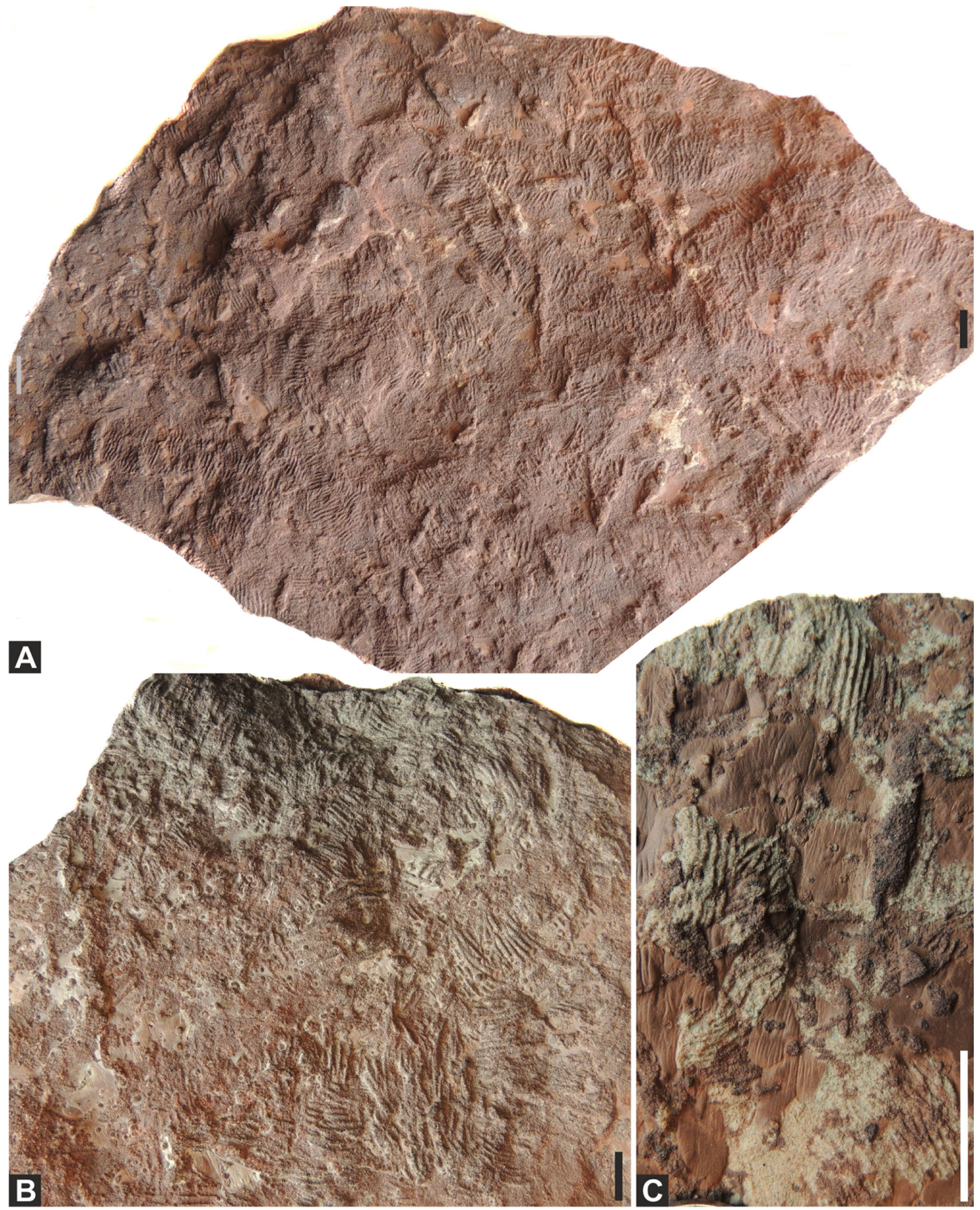

Figure 5. Showing small and big ridges on siltstone/sandstone slab (scale bar $=1.0 \mathrm{~cm}$ for a, b, c). (a) Slab with group of ridges in different directions showing busy locomotion probably by number of $K$. vagans in different directions. (BSIP Specimen No: BSIP-40434). (b) Small sinuous pattern of ridges on uneven surface of siltstone (BSIP Specimen No: BSIP40435). (c) Straight to slight sinuous bunch of ridges showing thinner in length and taper at the end on the bedding plane. (BSIP Specimen No: BSIP-40436). 


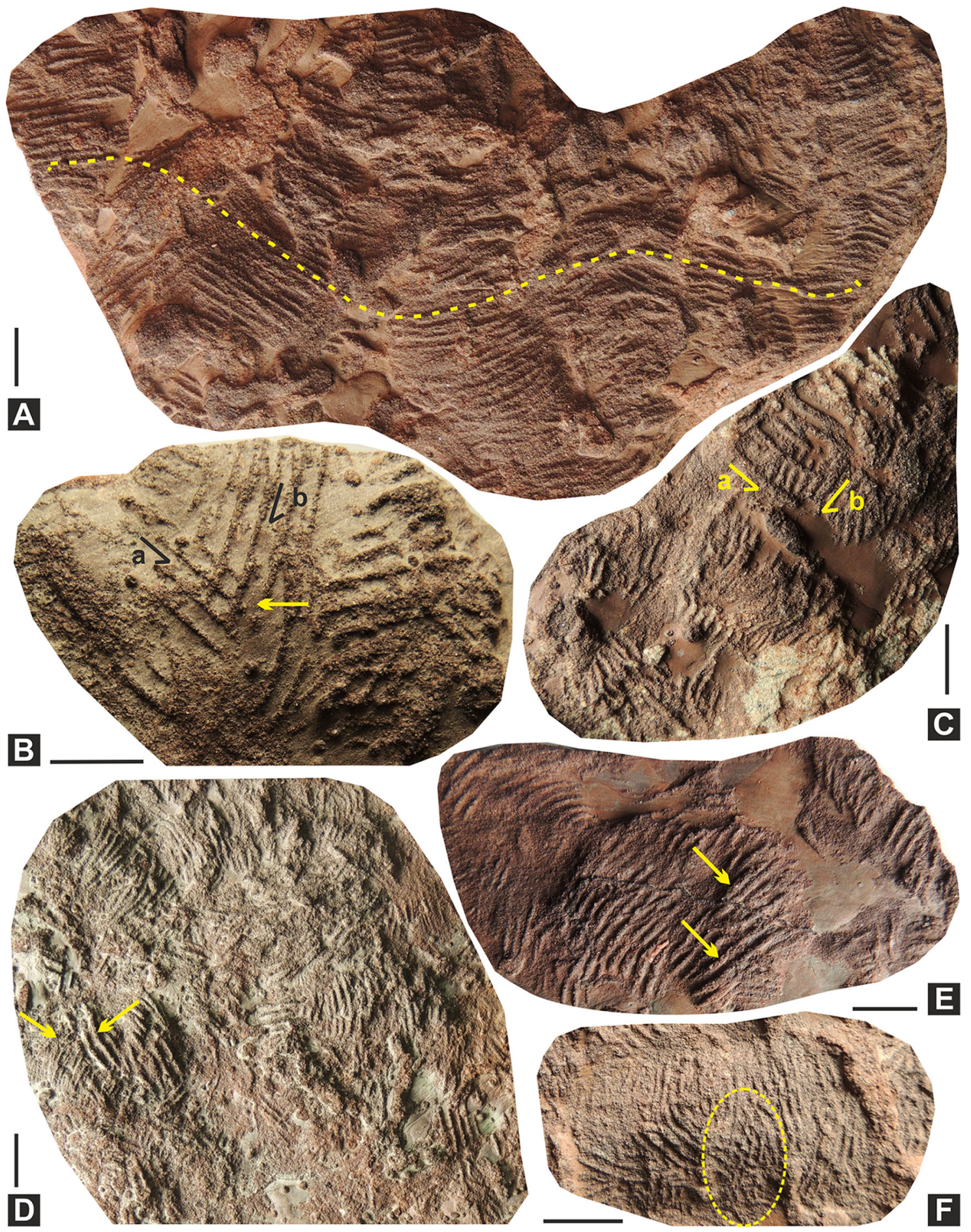

Figure 6. Different types of ridge pattern probably produced by $K$. vagans preserved on the bedding plane (scale bar $=1.0 \mathrm{~cm}$ for $\mathrm{a}-\mathrm{f})$. (a) Group of long sinuous ridges on the bedding plane showing wavy pattern probably produced by K. vagans; dotted line gives more clear overview of slow locomotion/diving. (BSIP Specimen No: BSIP-40430). (b) Crisscross pattern of ridges show two different individuals. White arrow shows the crossing junction, which forms square which indicates identical shape and size of probable K. vagans (BSIP Specimen No: BSIP-40437). (c) Same criss-cross pattern produced by the raptorial appendage of arthropod showing two different direction of locomotion (a and b); produced by probably two different size of arthropod; 'a' produced by big appendage whereas 'b' by smaller one. (BSIP Specimen No: BSIP-40438). (d) Slab showing different size of traces; ridges showing by white arrow are bigger and deeper in plan view. (BSIP Specimen No: BSIP-40435). (e) Beautifully preserved traces showing its sinuous linearly arranged pattern. Pattern showing by white arrow indicate irregular arrangement of exopod of $K$. vagans. (BSIP Specimen No: BSIP-40432). (f) Obliquely criss-crossed sinuous pattern of ridges showing locomotion in different direction near the sediment water interface. (BSIP Specimen No: BSIP-40434). 
Mikuláš 1995); Santa Rosita Formation, Argentina and Beach Formation, Bell Island, Eastern Newfoundland from the upper Cambrian to lower Ordovician (Fillion and Pickerill 1990; Mángano et al. 1996, 2005).

\section{Statistical analysis}

Data were collected on 22 specimens. Descriptive statistics was calculated for four variables: thickness of ridge $(\mathrm{T})$, distance between ridges $(\mathrm{D})$, number of ridges $(\mathrm{R})$ and length of the ridge $(\mathrm{L})$ (figure $7 \mathrm{a}$; supplementary table S1). Scatter diagram have been prepared between (R) with ' $T$ ', ' $D$ ', and ' $L$ ', which shows relationship between ' $R$ ' and 'T'; 'D' and 'L', respectively (figure 7b-d). Average distance was found to be $1.05 \mathrm{~mm}$ with very slight standard deviation $0.33 \mathrm{~mm}$ with negatively skewed distribution (figure 8c). Average length of the specimen was found to be $12.64 \mathrm{~mm}$ with the standard deviation of $2.32 \mathrm{~mm}$ with almost symmetrical distribution (figure 8a). The average number of ridges was found to be 8.13 with the standard deviation of 2.06 with a slightly positive skewness (figure $8 \mathrm{~d}$ ). The mean thickness was found to be $0.46 \mathrm{~mm}$ with the standard deviation of $0.21 \mathrm{~mm}$ with a positively-skewed distribution (figure 8b).

Pearson Correlation (PC) between thickness and length of individual specimen was found to be statistically significant at 5\% level of significance $(r=0.457, p=0.037)$ (supplementary table S2). It shows that with the increase in length of ridge there is a corresponding increase in the thickness of the ridge. Also, the correlation between thickness and number of ridges was found to be statistically significant at $5 \%$ level of significance $(r=0.454, p=0.039)$ (supplementary table S2 for correlation). This indicates increase in the size (number of ridges) that could be attributed to the extra requirement of food by adult individual thereby requiring more grazing to obtain enough food for survival. It is again substantiated by the regression analysis (supplementary table S3 for regression analysis) that the numbers of ridges are only influenced by thickness and other variables like distance and length were not found to be statistically significant in explaining the number of ridges in each specimen (supplementary table S2).

Cluster Analysis (CA) in which the procedure attempts to identify relatively homogeneous groups of cases (or variables) based on selected characteristics, using an algorithm that starts with each case (or variable) in a separate cluster and combines clusters until only one is left. The results can be displayed by dendrogram which is a graphical representation of hierarchical clusters. The purpose of a dendrogram is to display the relationships among distinct units by grouping them into smaller and smaller clusters. The technique of cluster analysis is useful tool for data analyses in several different situations; for example, this may be used to search for natural groupings in the data. Given a sample of ' $n$ ' objects, each of which has a score on p-variables, the aim is to devise a scheme for grouping the objects into clusters (or groups) so that 'similar' ones are in the same class. Cluster Analysis makes no assumption concerning the number of groups or the group structure. Grouping is done on the basis of some measure of resemblance of individuals in the whole group. There are various clustering algorithm available (Kaufman and Rousseeuw 2009). In this paper, the dendrogram was created using SPSS version 22 package. Dendrograms can be used to assess the cohesiveness of the clusters formed and can provide information about the appropriate number of clusters to keep. Cluster Analysis (CA) was performed on these specimens using average linkage (between groups). Result from the Dendrogram (figure 9) suggests that all the specimens belong to one group $M$. multilineatus except the one represented by no. 21. CA once again establishes that all the specimens reported in the paper were made by one species of the organism.

\section{Discussion}

\subsection{Global distribution}

Genus Monomorphichnus, with 16 species, has been established abundantly from nearly all the continents (table 2) and occur in the sediments ranging in age between lower Cambrian up to Cretaceous (figure 10 and references therein). Crimes (1970) first reported the genus Monomorphichnus from the upper Cambrian (Ffestiniog Stage $=\sim 514 \mathrm{Ma}=$ Series 2) strata of North Wales, where the traces were recorded. The species M. multilineatus was reported from the lower Cambrian rocks of the White-Inyo Mountains, California, USA (Alpert 1976). It is very 


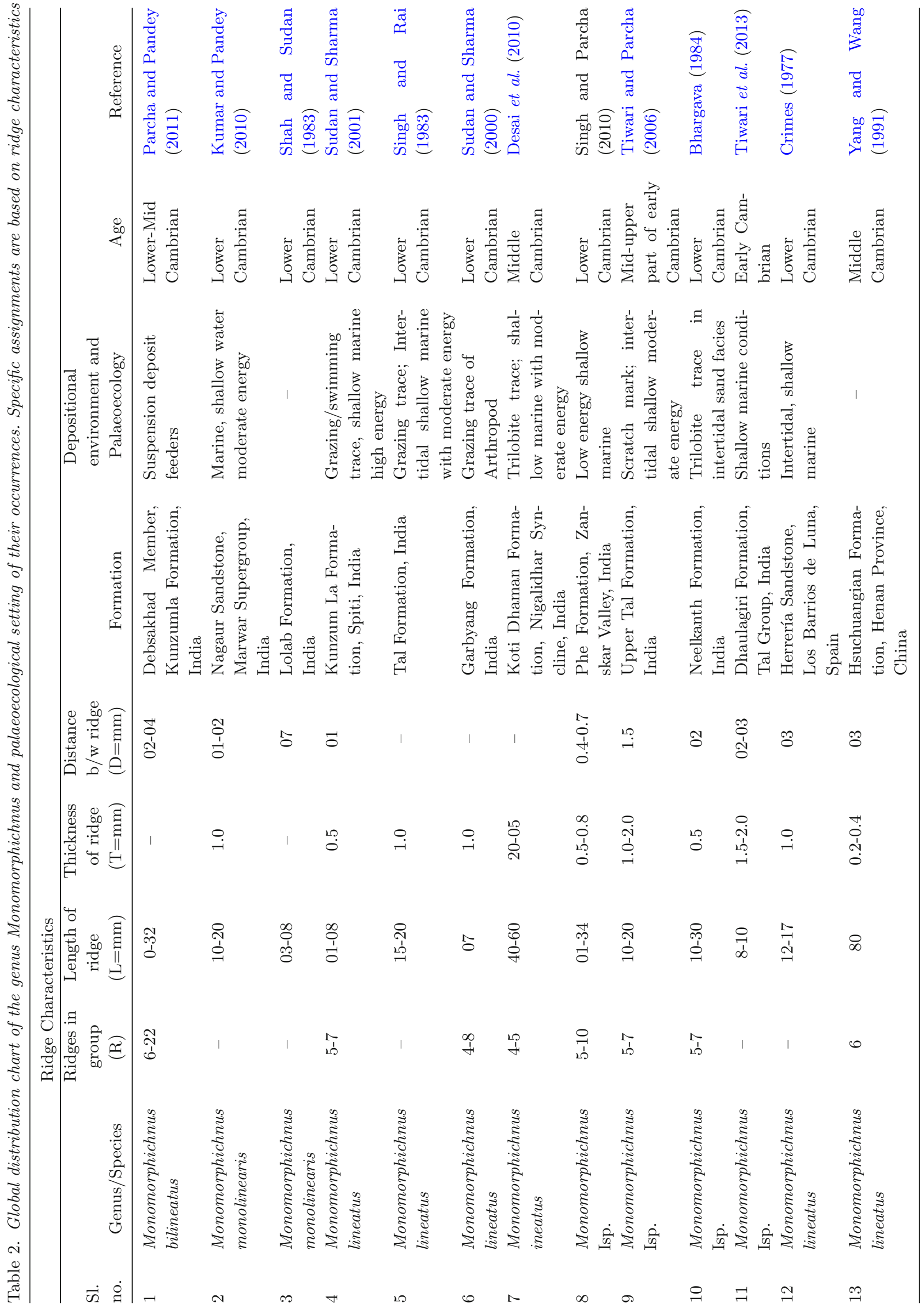




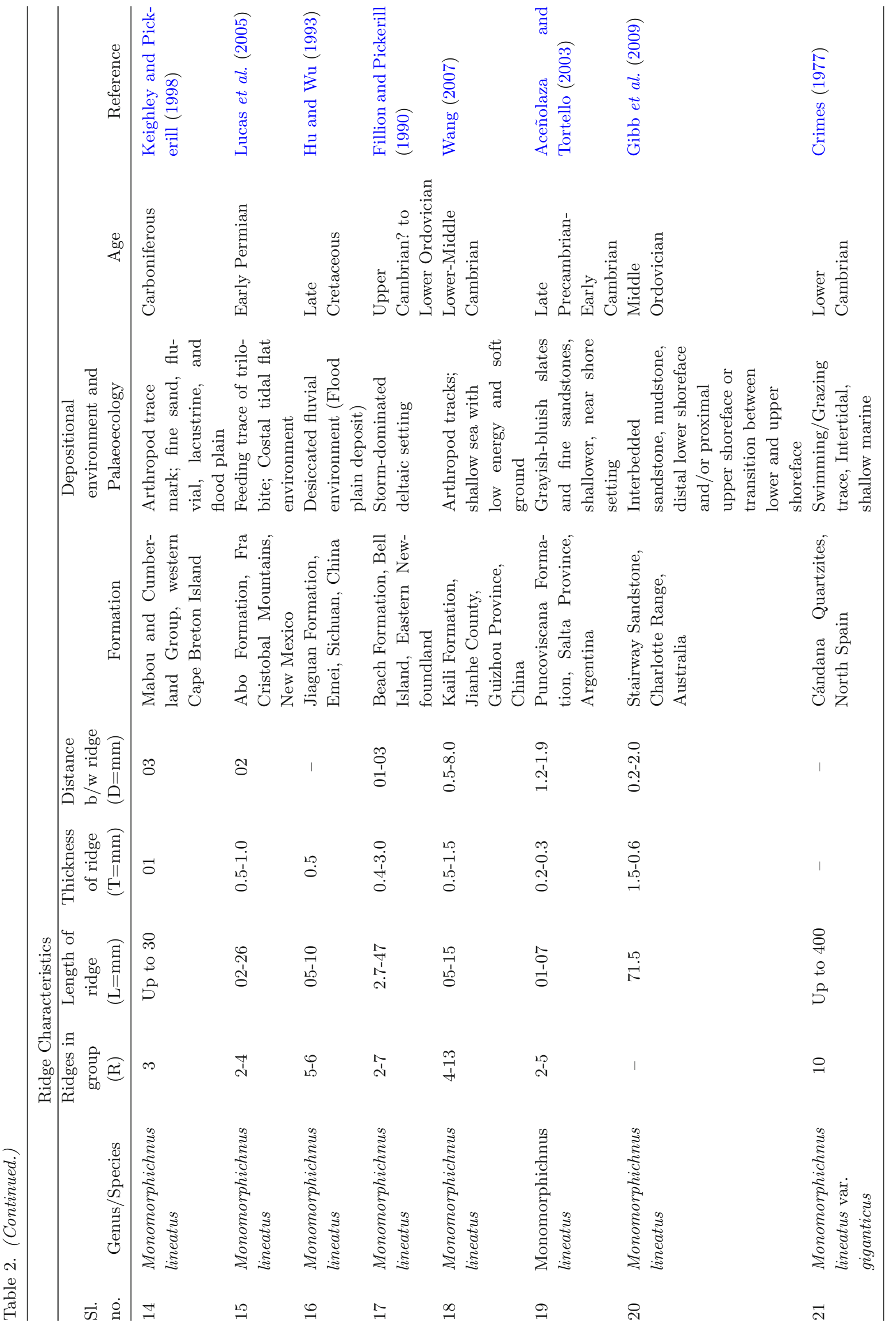




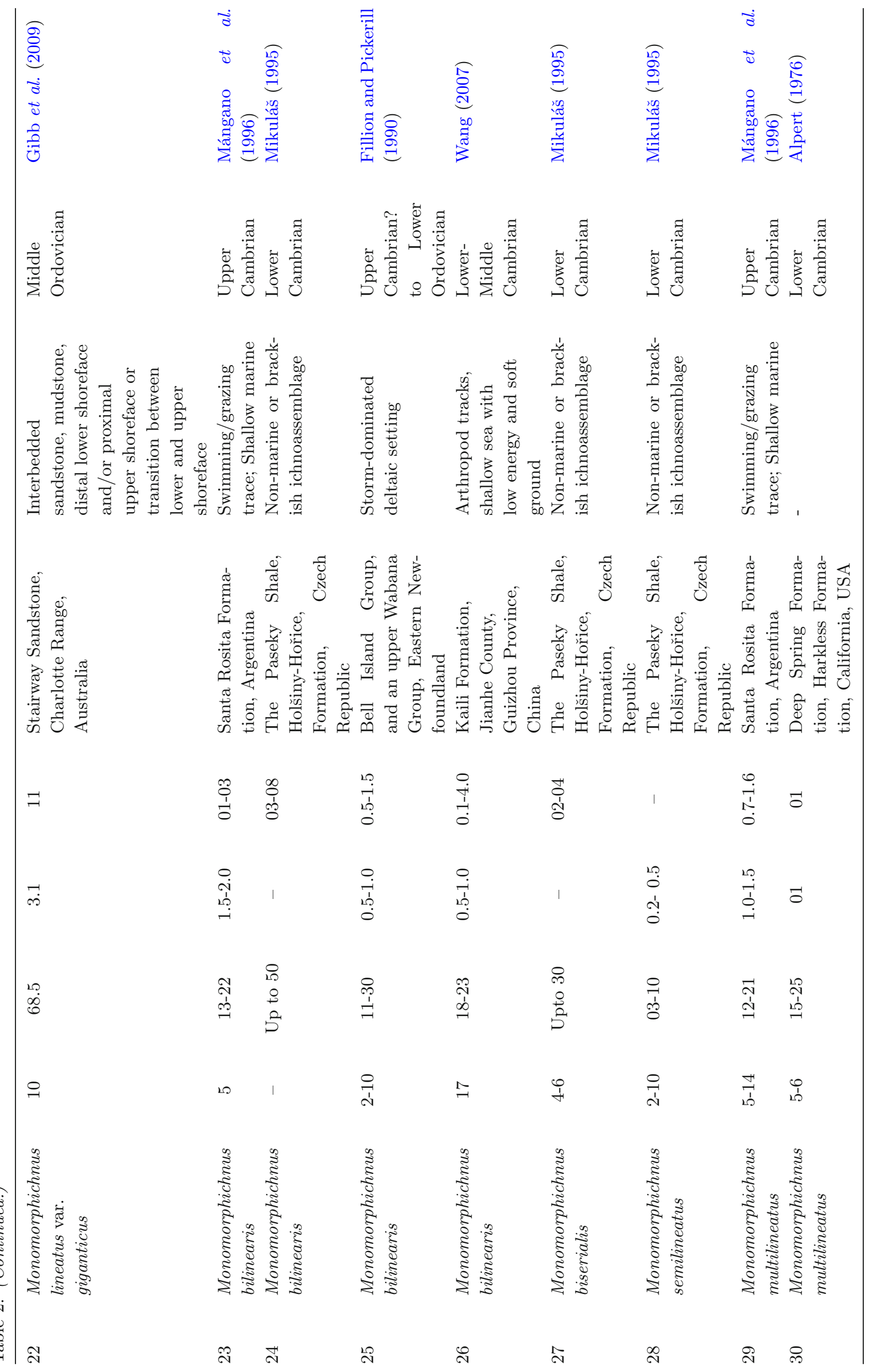




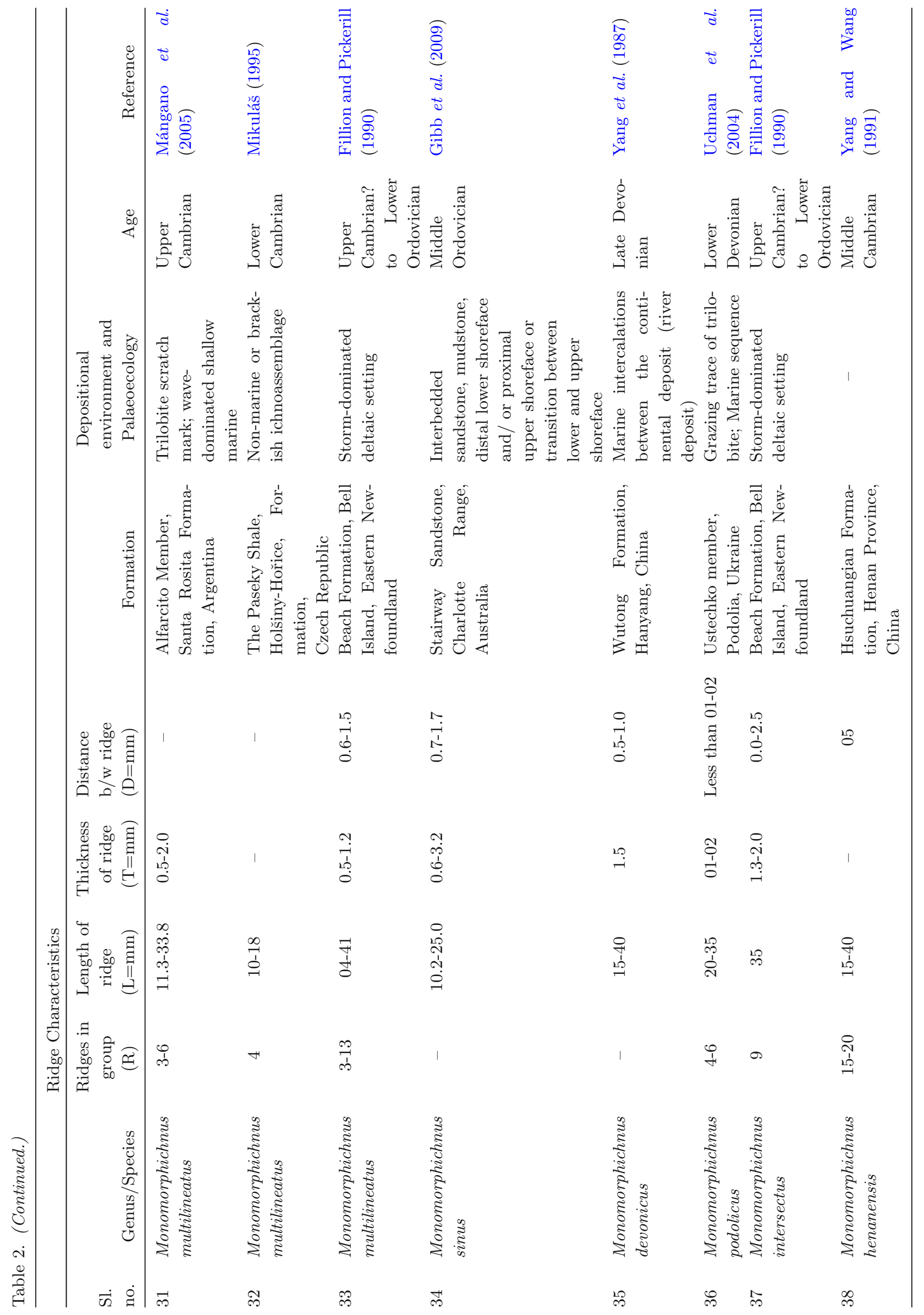




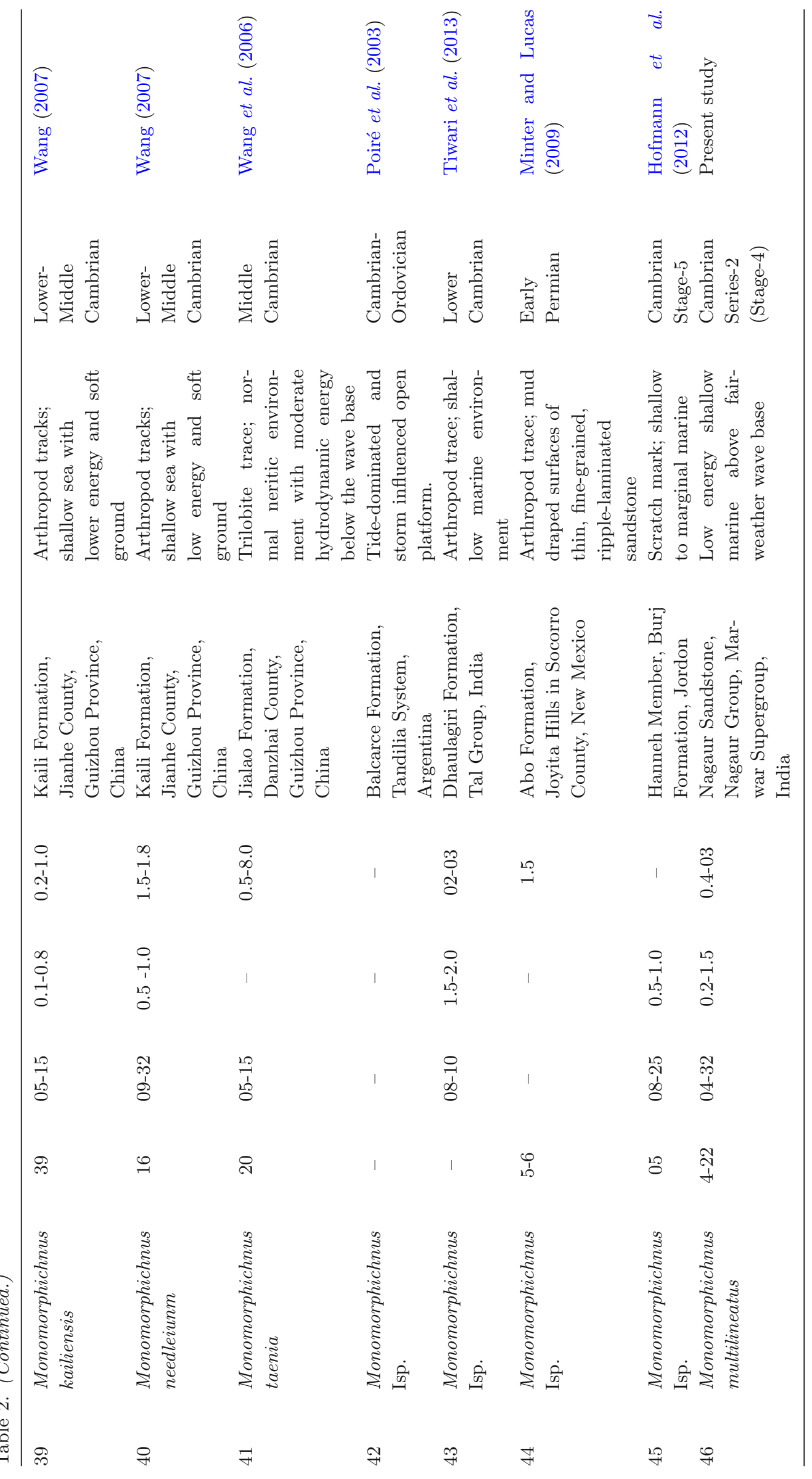



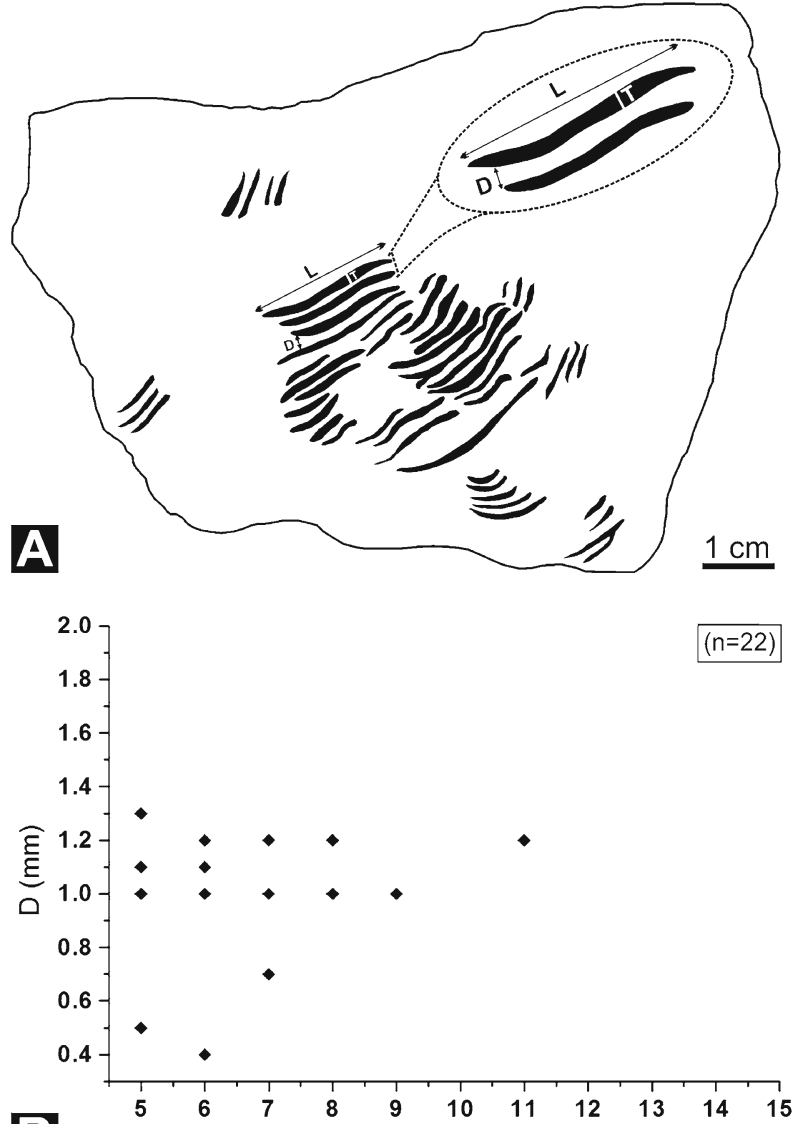

$\mathbf{B}$

(R)
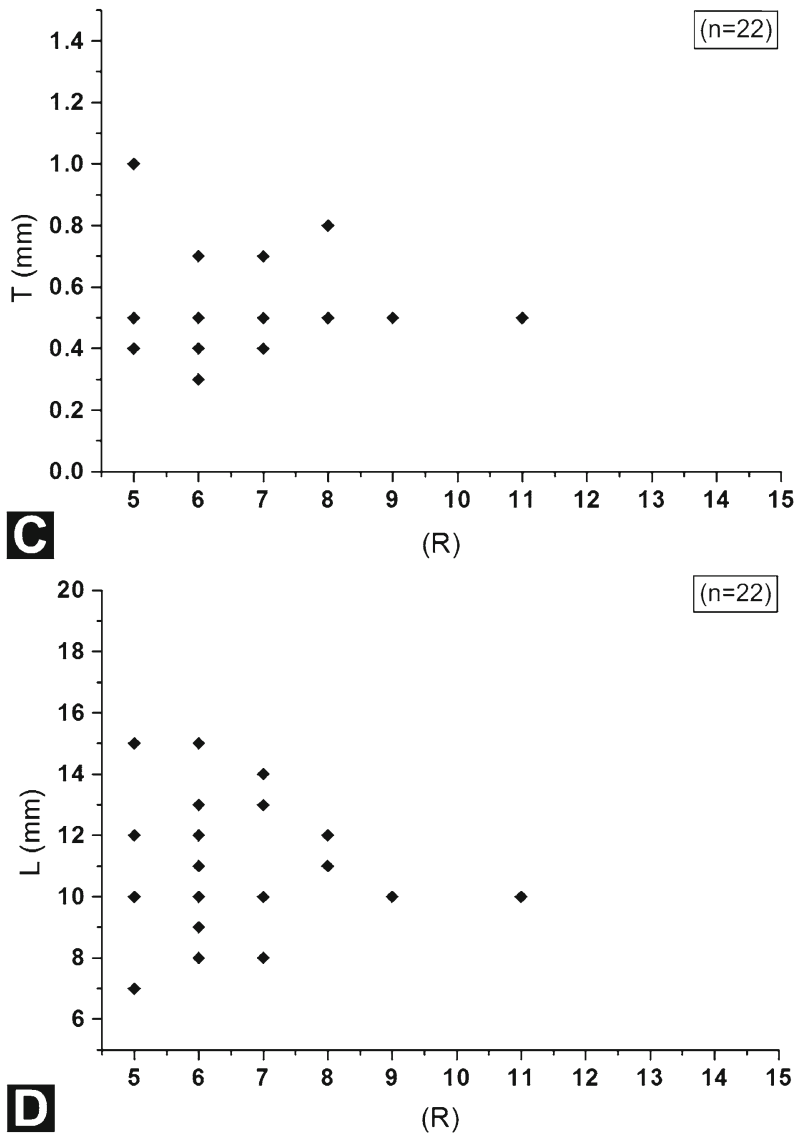

sparse in distribution and confined to the Cambrian Period except one report from Beach Formation, Newfoundland where it has been recorded from the lower Ordovician rocks (Fillion and Pickerill 1990) (figure 10). Parallel scratch marks characterized this species which is believed to have been formed by moving appendages of trilobite (Bergström 1973; Mikuláš 1995; Mángano et al. 1996, 2005).

Global distribution of genus Monomorphichnus is given in table 2. From India, species other than $M$. multilineatus are recorded from different formations that include $M$. bilineatus, $M$. monolinearis and M. lineatus from the Parahio Formation, the Lolab Formation, the Tal Formation, the Garbyang Formation, the Koti-Dhaman Formation, the Phe Formation, the Neelkanth Formation (Shah and Sudan 1983; Singh and Rai 1983; Bhargava 1984; Sudan and Sharma 2000, 2001; Tiwari and Parcha 2006; Kumar and Pandey 2008, 2010; Desai et al. 2010; Parcha and Singh 2010; Parcha and Pandey 2011; Tiwari et al. 2013). The other records of the genus Monomorphichnus are: Spain (Crimes 1977); China (Yang et al. 1987; Yang and Wang 1991; Hu and Wu 1993; Wang et al. 2006; Wang 2007); Western Cape Breton Island (Keighley and Pickerill 1998); New Mexico (Lucas et al. 2005; Minter and Lucas 2009); Eastern Newfoundland (Fillion and Pickerill 1990); Argentina (Mángano et al. 1996, 2005; Aceñolaza and Tortello 2003; Poiré et al. 2003); Australia (Gibb et al. 2009); Czech Republic (Mikuláš 1995); USA (Alpert 1976); Ukraine (Uchman et al. 2004) and Jordan (Hofmann et al. 2012). The species M. multilineatus has been recorded from Newfoundland (Canada), Argentina, Czech Republic and USA. From India, it is the first report of M. multilineatus.

Figure. 7. (a) Line drawing of $M$. multilineatus from the Nagaur Sandstone (BSIP Specimen No: BSIP-40432). Enlarge view in dotted ellipse where $\mathrm{L}=$ length of ridge; $\mathrm{T}=$ Thickness of ridge; $\mathrm{D}=$ Distance between two ridges (b) Scatter diagram representing 'unimodel' relationship between $\mathrm{D}$ and $\mathrm{R}$ (number of ridges) $(n=22)$. (c) Scatter diagram representing 'unimodel' relationship between T and $\mathrm{R}$ (number of ridges) $(n=22)$. (d) Scatter diagram representing 'unimodel' relationship between $\mathrm{L}$ and $\mathrm{R}$ (number of ridges) $(n=22)$. 

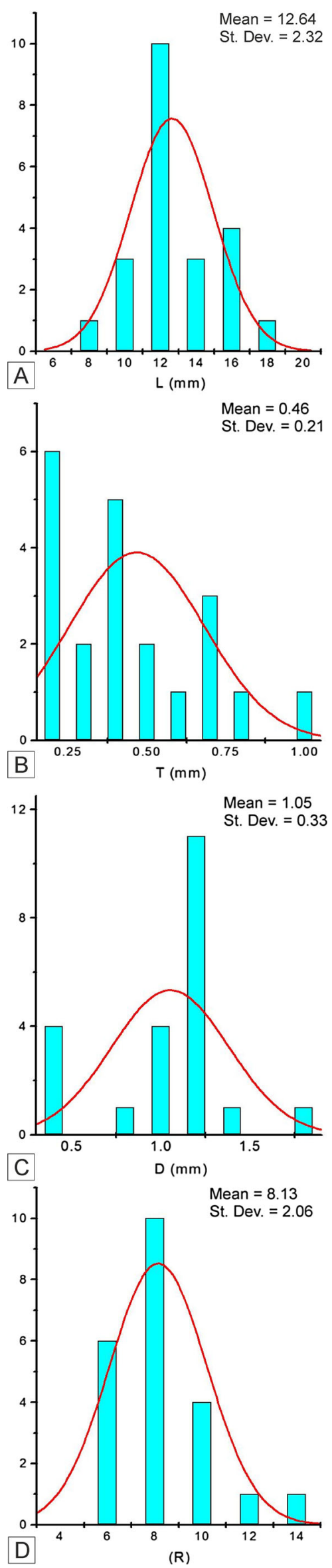

\subsection{Age connotation}

The distinctive fossils of Stage 2 (denoting the base of Stage 2), such as small shelly fauna, archaeocyatha and micromollusk, i.e., Watsonella crosbyi are lacking in the Nagaur assemblage. Characteristically, both these fossils are facies controlled and occur in carbonate rocks. In the absence of a carbonate unit in the Nagaur section at Dulmera, the presence or absence of these fossils could not be ascertained. FAD of T. pedum marks the base of Fortunian Stage. Trace fossil T. pedum has, although, been documented by various researchers (Srivastava 2012a; Ahmad and Kumar 2014; Pandey et al. 2014), its FAD in the Nagaur Sandstone is not conclusively well established. The total thickness of Nagaur Sandstone is $\sim 500 \mathrm{~m}$, whereas this assemblage of trace fossils is reported from a very restrictive exposure of $18 \mathrm{~m}$ at Dulmera; therefore, chances of finding ichnofossils at different underlying levels in the unexposed sections cannot be ruled out. The presence of $T$. pedum thus, in the present context, could not be considered as FAD (Sharma et al. 2018) to draw any conclusion regarding the $\mathrm{Pc}-\mathrm{C}$ boundary in the Nagaur Sandstone. The onset of Stage 3 is denoted by FAD of trilobite along with SSF and micromollusk. In recent publications, Pandey et al. (2014) and Singh et al. (2014) considered that the ichnofossils of the Nagaur Sandstone belong to Terreneuvian Series, Stage 2, but the overlying beds neither show the presence of any diagnostic short-ranged earliest Cambrian fossils nor there are any convincing evidence that these sediments are Stage 2 and therefore, there is not enough evidence for the sediments to be considered to be belonging to Terreneuvian Series. Hughes (2016) evaluated various age propositions for the

Figure 8. Descriptive statistics was calculated for four variables: thickness of ridge $(\mathrm{T})$, distance between ridges (D), number of ridges $(\mathrm{R})$ and length of the ridge $(\mathrm{L})$. (a) Average length of specimen was found to be $12.64 \mathrm{~mm}$ with the standard deviation of $2.32 \mathrm{~mm}$ with almost symmetrical distribution. (b) The mean thickness was found to be $0.47 \mathrm{~mm}$ with the standard deviation of $0.21 \mathrm{~mm}$ with a positively skewed distribution. (c) Average distance was found to be $1.05 \mathrm{~mm}$ with very small standard deviation $0.33 \mathrm{~mm}$ with negatively skewed distribution. (d) The average number of ridges was found to 8.13 with the standard deviation of 2.06 with a slightly positive skewness. 
Nagaur assemblage by different authors and on the basis of occurrence of questionably referred to Psammichnites favoured end of Stage 4, i.e., 510 Ma age within the $P$. gigas ichnozone for the Dulmera outcrops. The Stage 2 of the Terreneuvian Series, Stage 3, and 4 of Series 2, Stage 5 of Series 3 are still undefined on the geological timescale (Peng et al. 2012). Therefore, the placement of Nagaur trace-fossil assemblage and their assignment to trace fossil zone, although appear to be imprecise and open, considering the entire assemblage and questionable form of Psammichnites, it is placed near the end Stage 4 of the Cambrian, i.e., $~ 510$ Ma age (Hughes 2016). Mackenzie et al. (2011) dated the detrital zircons obtained from the fossil-bearing sandstone horizons and deduced the age of the Nagaur Sandstone cannot be older than $540 \mathrm{Ma}$, which also supports the palaeontological evidence.

\subsection{Palaeoecological significance}

Turbulence in any depositional realm is strongly the controlling factor for the distribution of ichnofossils in any succession. This fact has been observed in several studies (Crimes 1977; MacNaughton and Narbonne 1999). The presence of nutrients in any environment is important in the distribution of organisms, but it is difficult to estimate the crucial role played by it (Boucot 1981). Deposit feeding is dominant in nearly all the ichnofossils of the burrowed facies which is typical of Neoproterozoic and earliest Cambrian. This is considered as an indication of predation behaviour, first evolved as a strategy to utilize the unexplored nutrient rich zones and later used as protective shelters from predators (McMenamin 1986). M. multilineatus scratch marks are indicative of scouring behaviour evolved by the organisms of the tidal regime.

Well preserved ichnofossils of the Nagaur Sandstone along with the $M$. multilineatus rule out the soup ground and rare or absence of any fine external ornamentation on faunal burrows mark makes this assemblage most suitable for soft ground community (Ekdale et al. 1984). Detailed observations made on the ichnofossil M. multilineatus in preceding descriptions and depositional environmental inferences drawn on the study of the exposures at Dulmera allow to understand ecological limiting factors of ichnotaxa of which exposure, salinity, turbulence and substrate are important. There are very few restrictive horizons in Dulmera section which show desiccation polygons, rain prints or any other evidence of exposure and poor record of terrestrial trace producers suggest that organisms with protective carapaces or exoskeleton did not evolve by the early Cambrian. There is no direct and indirect evidence of increased salinity in the Nagaur Sandstone exposures. Globally, depositional environment of M. multilineatus bearing rocks varies from wave dominated shallow/moderate marine, storm dominated deltaic to non-marine brackish water environment (table 2). The depositional environment of $M$. multilineatus bearing Nagaur Sandstone offers some observations which help interpret the palaeoecology of this species. $M$. multilineatus occurs in red coloured lithofacies of Nagaur Sandstone that indicate the highly oxidized environment; trace fossils are confined to fine to medium grained, ferruginous sandstone with clay, which deposited in low energy shallow water environment just above fair-weather wave base. Small to large scale trough cross bedding with intercalation of red maroon colour fragile siltstone/shale with rain-prints, syneresis and mud cracks are in abundance and also indicate shallow water depositional environment with episodic exposure.

Trace fossils, similar to M. multilineatus, were originally considered as grazing traces, formed by the arthropods and/or trilobites (Bergström 1973; Mikuláš 1995; Mángano et al. 1996, 2005). While gliding/floating in shallow water column, during the feeding activity, these organisms left the scratch marks made by their appendages on the sediment-water interface (Mikuláš 1995; Mángano et al. 1996, 2005). The sandstone mudstone interfacies of the Nagaur Sandstone, indicate distinct aerobic environment supporting the existence of biotic activities (bioturbation activity Palaeophycus, Planolites and Bergaueria). Profuse development of traces of $M$. multilineatus on the bedding plane suggests the abundance of existing crustaceans/arthropod/molluscs and worms and complex intrinsic food chain supported by high productivity in the depositional realm. With the development of still complex food web in younger geological sequences, only a few species survived up to Cretaceous and some found refuge in non-marine/fluvial/brackish/ deltaic settings. 
Table 3. Characteristic features of Monomorphichnus multilineatus recorded from the Nagaur Sandstone, Marwar Supergroup, Rajasthan, India.

\begin{tabular}{|c|c|c|c|c|c|c|}
\hline & Ridge char & acteristics & & & & \\
\hline $\begin{array}{l}\text { BSIP } \\
\text { Specimen no. }\end{array}$ & $\begin{array}{l}\text { Ridges in } \\
\text { group } \\
(\mathrm{R})\end{array}$ & $\begin{array}{l}\text { Length of } \\
\text { ridge } \\
(\mathrm{L}=\mathrm{mm})\end{array}$ & $\begin{array}{l}\text { Thickness } \\
\text { of ridge } \\
(\mathrm{T}=\mathrm{mm})\end{array}$ & $\begin{array}{l}\text { Distance } \\
\mathrm{b} / \mathrm{w} \text { ridge } \\
(\mathrm{D}=\mathrm{mm})\end{array}$ & Formation & Remarks \\
\hline 40436 & $5-7$ & $05-18$ & $0.5-0.8$ & 1.0 & Nagaur Sandstone & $\begin{array}{l}\text { Straight to sinuous thick ridges on red } \\
\text { sst }\end{array}$ \\
\hline 40433 & $6-9$ & $09-15$ & 0.5 & 1.0 & Nagaur Sandstone & $\begin{array}{l}\text { Straight to sinuous thin ridges on iron } \\
\text { sst; sometime overlap one another }\end{array}$ \\
\hline 40432 & $5-15$ & $05-32$ & $0.5-1.0$ & $0.8-1.5$ & Nagaur Sandstone & $\begin{array}{l}\text { Straight thin ridges on flat bedded red } \\
\text { sst }\end{array}$ \\
\hline 40431 & $5-12$ & $05-26$ & $0.5-1.0$ & $0.8-1.5$ & Nagaur Sandstone & $\begin{array}{l}\text { Straight thin ridges on flat bedded red } \\
\text { sst }\end{array}$ \\
\hline 40430 & $6-15$ & $05-25$ & $0.5-1.5$ & $1.5-1.0$ & Nagaur Sandstone & $\begin{array}{l}\text { Straight to sinuous thin ridges on red } \\
\text { sst; branching seen }\end{array}$ \\
\hline 40435 & $4-17$ & $05-22$ & $0.4-1.2$ & $0.5-2.0$ & Nagaur Sandstone & $\begin{array}{l}\text { Straight to sinuous thin ridges on iron } \\
\text { sst, branching seen }\end{array}$ \\
\hline 40434 & $4-22$ & $05-20$ & $0.4-0.6$ & $0.5-2.0$ & Nagaur Sandstone & $\begin{array}{l}\text { Straight to sinuous thick ridges on red } \\
\text { sst; overlapping seen with some cracks }\end{array}$ \\
\hline 40451 & $5-10$ & $10-20$ & 0.5 & 1.0 & Nagaur Sandstone & $\begin{array}{l}\text { Straight to sinuous thin ridges on red } \\
\text { sst }\end{array}$ \\
\hline 40450 & $5-6$ & $10-15$ & 0.5 & $1.0-1.2$ & Nagaur Sandstone & $\begin{array}{l}\text { Straight thick ridges on red sst with } \\
\text { high relief }\end{array}$ \\
\hline 40441 & $4-6$ & $10-15$ & $0.3-0.5$ & $1.0-1.2$ & Nagaur Sandstone & $\begin{array}{l}\text { Straight to sinuous thick ridges on red } \\
\text { sst associated with Bergaueria }\end{array}$ \\
\hline 40439 & $5-7$ & $10-15$ & 0.5 & 1.0 & Nagaur Sandstone & $\begin{array}{l}\text { Straight to sinuous thick ridges on iron } \\
\text { sst; branching seen }\end{array}$ \\
\hline 40447 & $4-7$ & $05-15$ & 1.0 & $0.5-2.0$ & Nagaur Sandstone & $\begin{array}{l}\text { Straight to sinuous ridges on iron sst; } \\
\text { (In negative relief) }\end{array}$ \\
\hline 40438 & $5-12$ & $05-20$ & $0.2-0.5$ & $0.5-3.0$ & Nagaur Sandstone & $\begin{array}{l}\text { Straight to sinuous small and big ridges } \\
\text { on red sst }\end{array}$ \\
\hline 40442 & $4-14$ & $05-20$ & $0.3-0.5$ & $0.5-1.5$ & Nagaur Sandstone & $\begin{array}{l}\text { Sinuous ridges on iron sst with high } \\
\text { relief }\end{array}$ \\
\hline 40437 & $5-12$ & $05-22$ & 0.5 & $0.5-2.0$ & Nagaur Sandstone & $\begin{array}{l}\text { Sinuous ridges on iron sst with high } \\
\text { relief }\end{array}$ \\
\hline 40443 & $5-12$ & $05-25$ & $0.5-0.6$ & 01-02 & Nagaur Sandstone & $\begin{array}{l}\text { Straight to sinuous uniform ridges on } \\
\text { red sst associated with Palaeophycus }\end{array}$ \\
\hline 40448 & $5-17$ & $05-18$ & $0.4-0.5$ & $0.5-1.5$ & Nagaur Sandstone & $\begin{array}{l}\text { Straight to sinuous big ridges on iron } \\
\text { sst associated with Skolithos; overlap- } \\
\text { ping present }\end{array}$ \\
\hline 40444 & $4-12$ & $04-22$ & $0.3-0.6$ & $0.5-1.8$ & Nagaur Sandstone & $\begin{array}{l}\text { Straight to sinuous small ridges on iron } \\
\text { sst; overlapping present }\end{array}$ \\
\hline 40446 & $4-13$ & $04-17$ & $0.3-0.5$ & $0.5-1.5$ & Nagaur Sandstone & $\begin{array}{l}\text { Straight to sinuous small and big ridges } \\
\text { on iron sst; overlapping present }\end{array}$ \\
\hline 40440 & $3-12$ & $05-16$ & 0.5 & $0.5-2.0$ & Nagaur Sandstone & $\begin{array}{l}\text { Straight to sinuous ridges on iron sst; } \\
\text { overlapping present }\end{array}$ \\
\hline 40449 & $4-7$ & $05-10$ & $0.2-0.5$ & $0.4-0.6$ & Nagaur Sandstone & $\begin{array}{l}\text { Straight ridges on red sst, but not well } \\
\text { preserved }\end{array}$ \\
\hline 40445 & $5-14$ & $04-15$ & 0.5 & $0.5-1.0$ & Nagaur Sandstone & $\begin{array}{l}\text { Straight sharp ridges on iron sst with } \\
\text { mud clast; overlapping present }\end{array}$ \\
\hline
\end{tabular}




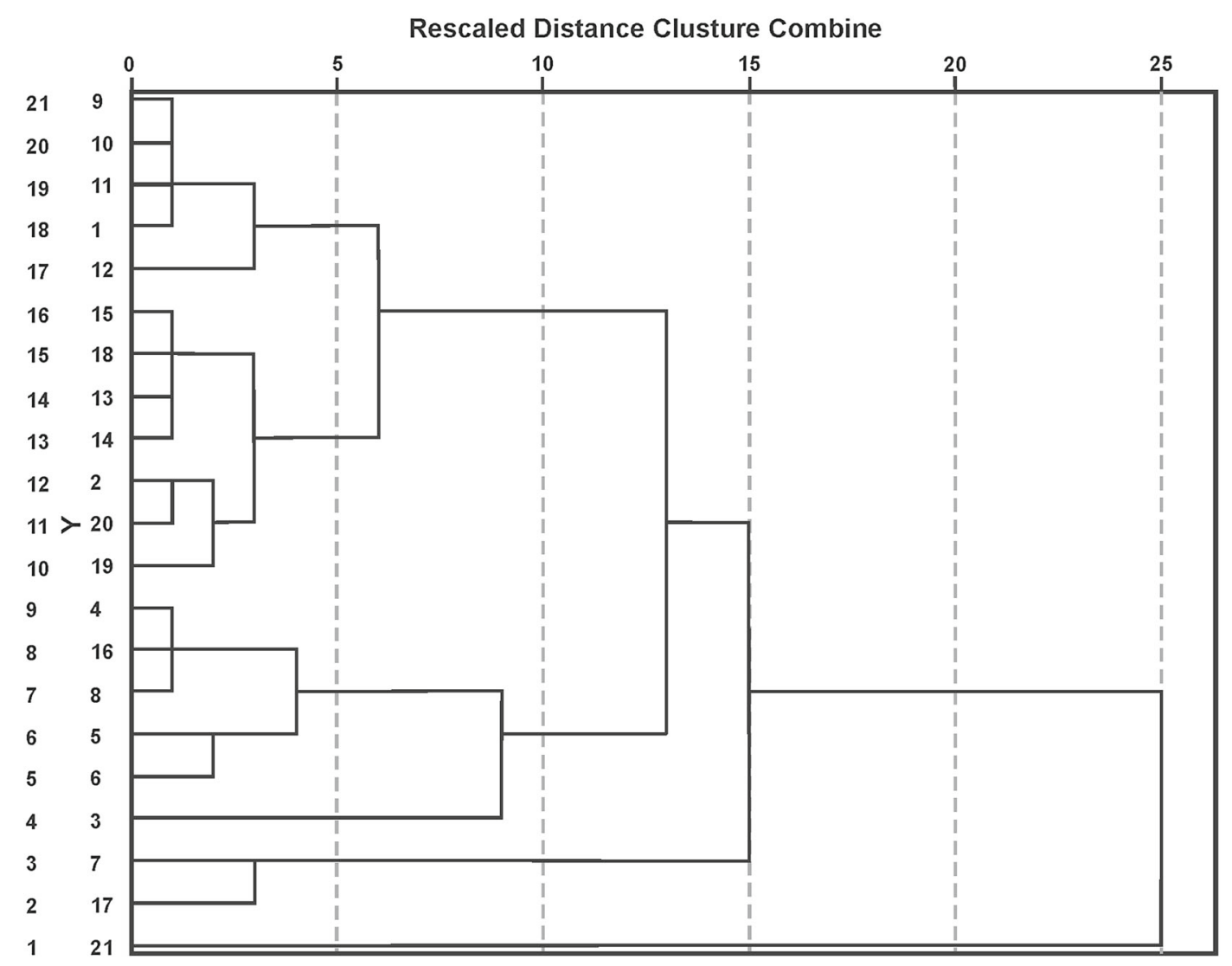

Figure 9. Dendrogram of 21 specimens analyzed in the present study using average linkage (between groups).

\subsection{Formation of M. multilineatus}

In early Cambrian marginal marine realm, enigmatic arthropod $K$. vagans is supposed to be the earliest known predator having ancestral trait of Crustaceans/eurypterids (sea scorpions, crab like arthropod and being close to trilobite; Mikuláš 1995). It is also considered to be the first arthropod with disarticulated head shield with trunk tergites (Chlupáč and Havlíček 1965). Mikuláš (1995) discussed the mode of preservation, type of animal and the circumstances under which these traces would have been produced by various modes of locomotion or by resting organism on the bottom of sediment and concluded that probably Monomorphichnus type traces are better explained to have been formed by the arthropod or trilobite.

Formation of traces of parallel scratch marks attributed to $M$. multilineatus are believed to be formed by the elongated spines of $K$. vagans, which was described from the Paseky Shale of the central Bohemia, Czech Republic (Chlupáč and Havlíček
1965) near the sediment water interface. $K$. vagans is believed to have a pair of raptorial appendages, which are considered to be the second cephalonic appendage (Lamsdell et al. 2013) that played an important role in the formation of scratch marks similar to Monomorphichnus type and led them to infer that $K$. vagans was an active swimmer. In shallow water or wave dominated aerobic environment, soft-bodied organisms such as small worms, crustaceans preferred inhabiting the top layer of sediments, which was also the favourable site for $K$. vagans while swimming and moving in search of food (figure 11a). In the highly toxic environment, Kodymirus ploughed the sediments with the help of its strong raptorial appendages. Exopod was the main weapons to scrap and catch the softbodied organisms, either buried or living within the sediment. Deep depressions in the middle of trace (hyporeleif) on the muddy surface indicate strong digging/ploughing traces in search of food by the $K$. vagans (figure $11 \mathrm{~b}-\mathrm{b} 2$ ), whereas ridges found on the sole of overlying sandy sediments (figure 11b-b1). 


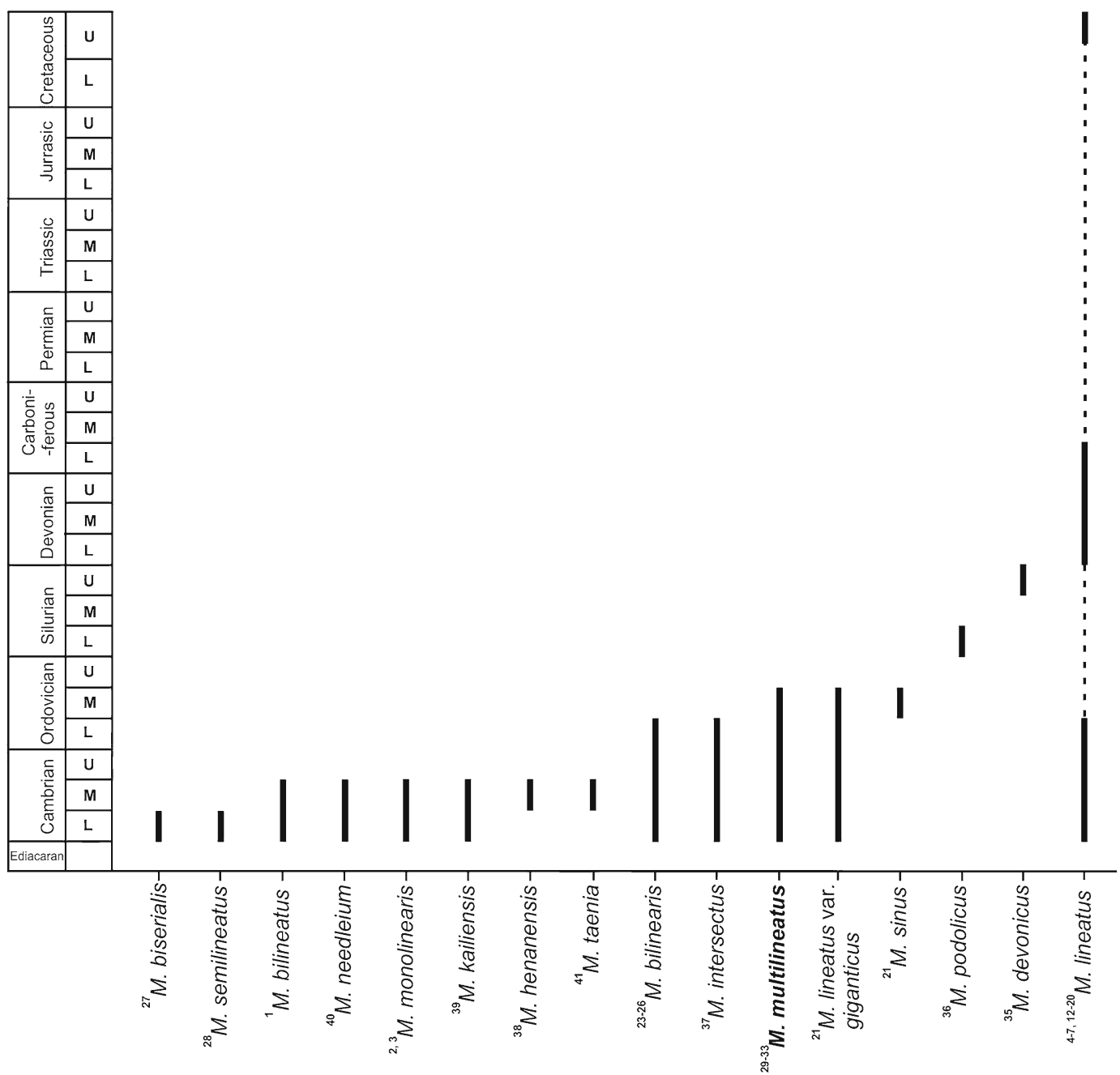

Figure 10. Range chart of Ichnogenus Monomorphichnus (source: Published data; see table 2; numbers denotes the specific row of the table).

\subsection{Palaeogeographic significance}

The genus Monomorphichnus is widely known from the lower to upper Cambrian age successions of Argentina, China, Czech Republic, India, Jordon, Newfoundland, Spain and USA (see table 2). There are a few records where this genus is reported from the younger succession ( $\mathrm{Hu}$ and $\mathrm{Wu} 1993$ and see table 2). In Indian context, the genus is recorded only from the lower to middle Cambrian age rocks of Himalaya and from the Marwar Supergroup where these traces are preserved in low to high energy depositional environment of marine successions. Comprehensive information on the global occurrences is summarized in table 2 and the authoritative summary on the Cambrian palaeontological records of Indian sub-continent is presented by Hughes (2016). But there is no record of the Monomorphichnus in the recent paper on Bhutan where upper Cambrian sediments are exposed (Singh et al. 2017). Kumar and Pandey (2010) proposed a sea-link of receding Cambrian sea through the Himalaya, Marwar Supergroup and Salt Range, Pakistan where the genus occurs in low to moderate energy shallow marine environment just above the fair-weather wave base. But, in the global context, depositional environment vary from marine to non-marine deposits. Some non-marine sequences of younger ages where this genus has been recorded include either fluvial, brackish water or storm dominated deltaic setting (table 2).

\section{Conclusions}

- Ichnofossil Monomorphichnus multilineatus is a grazing trace, produced by the $K$. vagans like 


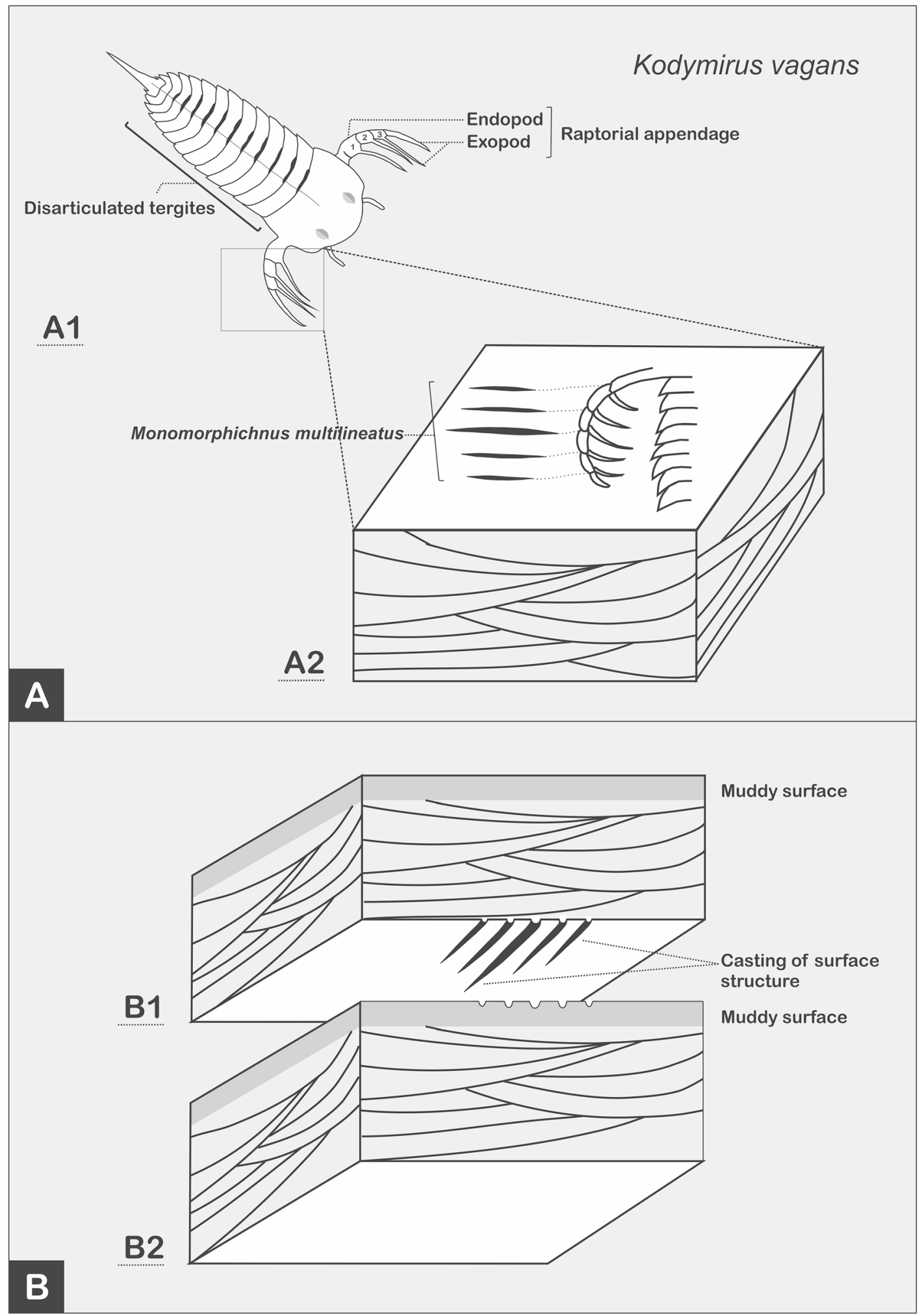

Figure 11. Model shows the preservation style of trace marks probably produced by K. vagans in the form of feeding/ locomotion/diving/grazing activity near the sediment water interface. (a) (A1) K. vagans; probable producer of M. multilineatus, showing strong hydrodynamic body posture divided into disarticulated tergites, cephalon, and raptorial appendage. Appendage is characterized by endopod and exopod, which are responsible for producing these traces. Rectangle block covers the raptorial appendage. (A2) Block diagram showing siltstone/sandstone bedding plane; during feeding exopod and endopod leave their traces on the sediment. (b) (B1) Sole of the bedding, which characterised by siltstone/sandstone encountered traces as epirelief. (B2) Top of the bedding plane characterised by muddy surface helps to preserve activities produced by appendages have been traced as hyporelief. 
arthropod. Trace producing organism inhabited the shallow water or wave dominated aerobic marginal marine environment just above the fairweather wave base in the Nagaur Sandstone.

- Fossil bearing half a meter thick litho-facies supports the existence of $M$. multilineatus and varied soft-bodied animals like worms, etc., in the Nagaur Sandstone.

- Cluster Analysis and dendrogram suggest that all the studied specimens belong to one group which formed M. multilineatus.

- Pearson Correlation between thickness and length of individual specimen was positive, which indicate that the requirement of food by adult individual specimen was more, and thereby requiring more grazing to provide enough food for survival.

- Present report of $M$. multilineatus from the Nagaur Sandstone is the first occurrence from India. It occurs in the end Stage 4 of the Series 2 of the Cambrian.

- Present record of M. multilineatus is from intertidal setting. In comparison, most of the other species of Monomorphicnus existed in the Cambrian to lower Ordovician age successions and their environment of deposition ranged between marine to non-marine. Only a few species survived up to Cretaceous and represented in non-marine/fluvial/brackish/deltaic setting for deposition.

- M. multilineatus preserved in the Nagaur Sandstone demonstrates the perfect example of 'relict of predation' by the arthropod $K$. vagans which was earliest known active predator within the marginal marine environment.

\section{Acknowledgements}

We are thankful to the anonymous reviewer and Prof. Nigel Hughes for very constructive suggestions offered on the earlier version of the manuscript. Mukund is indebted to Late Prof. B S Paliwal, JNV University for introducing the area and greatly benefited by the geological experience of Prof. Paliwal, and Late Dr R L Jain of the Geological Survey of India. Discussions with Profs. Nigel Hughes, Sören Jensen, S Kumar, M K Pandit, D K Pandey and S K Mathur helped us improve our arguments. We are grateful to the people of Dulmera village for allowing us access their lease areas and collect samples and data for this study for many years. The authors are thankful to Prof.
Sunil Bajpai, Director, Birbal Sahni Institute of Palaeosciences, for extending the facilities to carry out the investigations and permission to publish this work (RDCC/2017-18/4).

\section{References}

Aceñolaza G F and Tortello M F 2003 El Alisal: A new locality with trace fossils of the Puncoviscana Formation (late Precambrian-early Cambrian) in Salta Province, Argentina; Geol. Acta 1(1) 95-102.

Ahmad S and Kumar S 2014 Trace fossil assemblage from the Nagaur Group, Western India; J. Palaeontol. Soc. India 59(2) 231-246.

Alpert S P 1976 Planolites and Skolithos from the Upper Precambrian-Lower Cambrian White-Inyo mountains, California; J. Paleontol. 49(3) 508-521.

Ansari A H, Pandey S K, Sharma Mukund, Agrawal Shailesh and Kumar Yogesh 2018 Carbon and oxygen isotope stratigraphy of the Ediacaran Bilara Group, Marwar Supergroup, India: Evidence for high amplitude carbon isotopic negative excursions; Precamb. Res. 308 75-91.

Babu R, Singh V K and Shukla M 2009 Cryptic bioentities with their significance from the Gotan Formation of Bilara Group, Marwar Supergroup, Rajasthan; Curr. Sci. 96(12) 1575-1577.

Barman G 1980 An analysis of the Marwar Basin, western Rajasthan, in the light of stromatolite study; Geol. Surv. India Misc. Publ. 44 292-297.

Barman G 1987 Stratigraphical position of the Marwar Supergroup in the light of stromatolite study; Geol. Surv. India Spec. Publ. 11 72-80.

Behrensmeyer A K and Kidwell S M 1985 Taphonomy's contributions to palaeobiology; Palaeob. 11 105-119.

Bergström J 1973 Organization, life, and systematics of trilobites; Fossils and Strata 2 69p.

Bhargava O N 1984 Trace fossil from the Cambrian Tal Group, Sirmaur district, H.P. and proposed redefinition of the Tal; J. Palaeontol. Soc. India 29 84-87.

Bhatt D K, Prasad S and Jain R L 2002 Geological nature of the Pokaran Boulder Bed; palaeoenvironmental, palaeoclimatic and stratigraphic implications: Discussion and reply; J. Geol. Soc. India 60(3) 353-355.

Bose P K, Eriksson P G, Sarkar S, Wright D T, Samanta P, Mukhopadhyay S, Mandal S, Banerjee S and Altermann W 2012 Sedimentation patterns during the Precambrian: A unique record?; Mar. Petrol. Geol. 33 34-68.

Boucot A J 1981 Principles of Benthic Marine Paleoecology; New York, Academic Press, 463p.

Chauhan D S and Bhanwara R 1999 Ripple marks and synthesis of beach sequences: A study of early Palaeozoic sandstone of Jodhpur Group, Western Rajasthan; In: Geological Evolution of Western India (ed.) Paliwal B S, Scientific Publisher, Jodhpur, pp. 66-78.

Chauhan D S, Bhanwara R and Narayanan R 2004 Jodhpur sandstone: A gift of ancient beaches to Western Rajasthan; J. Geol. Soc. India 64 265-276.

Chlupáč I and Havlíček I 1965 Kodymirus n.g., a new aglaspid merostome of the Cambrian of Bohemia; $S b$. Geol. Věd. Paleontol. 6 7-20. 
Crimes T P 1970 Trilobite tracks and other fossils from the upper Cambrian of North Wales; Geol. J. 7(1) 4768.

Crimes T P 1977 Trace fossils of Eocene deep-sea sand fan, northern Spain; In: Trace fossils 2 (eds) Crimes T P and Harper J C, Geol. J. (Spec. Issue) 9 71-90.

Davis J K, Meert J G and Pandit M K 2014 Paleomagnetic analysis of the Marwar Supergroup, Rajasthan, India and proposed interbasinal correlations; J. Asian Earth Sci. 91 339-351.

Desai B G, Shukla R and Saklani R D 2010 Ichnology of the Early Cambrian Tal Group, Nigalidhar Syncline, Lesser Himalaya India; Ichnos 17 233-245.

Ekdale A A, Bromley R G and Pemberton S G 1984 Ichnology: The use of trace fossils in sedimentology and stratigraphy: Society of Economic Palaeontologists and Mineralogists short course no. 15 317p.

Erwin D H, Laflamme M, Tweedt S M, Sperling E A, Pisani D and Peterson K J 2011 The Cambrian conundrum: Early divergence and later ecological success in the early history of animals; Science 334(6059) 10911097.

Fillion D and Pickerill R K 1990 Ichnology of the Upper Cambrian to Lower Ordovician Bell Island and Wabana Groups of eastern Newfoundland, Canada; Palaeontogr. Canad. 7 1-119.

Gehling J G and Rigby J K 1996 Long expected sponges from the Neoproterozoic Ediacara fauna of South Australia; J. Paleontol. 70(2) 185-195.

George B G and Ray J S 2017 Provenance of sediments in the Marwar Supergroup, Rajasthan, India: Implications for basin evolution and Neoproterozoic global events; $J$. Asian Earth Sci. 147 254-270.

Gibb S, Brian D E, Chatterton and Pemberton S G 2009 Arthropod ichnofossils from the Ordovician Stairway Sandstone of central Australia; Mem. Assoc. Austr. Palaeontol. 37 695-716.

Gregory L C, Meert J G, Bingen G, Pandit M K and Torsvik T H 2009 Paleomagnetism and geochronology of the Malani Igneous Suite, Northwest India: Implications for the configuration of Rodinia and the assembly of Gondwana; Precamb. Res. 170 13-26.

Hofmann R, Mángano M G, Elicki O and Shinaq R 2012 Paleoecologic and biostratigraphic significance of trace Fossils from shallow- to marginal-marine environments from the middle Cambrian (Stage 5 ) of Jordan; J. Paleontol. 86(6) 931-955.

$\mathrm{Hu}$ Bin and Wu Xian-Tao 1993 Ichnofossils of Alluvial Jiaguan Formation (Upper Cretaceous), Emei, Sichuan, China; Acta Palaeontol. Sin. 32(4) 478-489.

Hughes N C 2016 The Cambrian palaeontological record of the Indian subcontinent; Earth Sci. Rev. 159 428-461.

Hughes N C, Myrow P M, McKenzie N R, Xiao S H, Banerjee D M and Tang Q 2015 Age and implications of the phosphatic Birmania Formation, Rajasthan, India; Precamb. Res. 267 164-173.

Kaufman L and Rousseeuw P J 2009 Finding groups in data: An introduction to cluster analysis; John Wiley and Sons, $344 \mathrm{p}$.

Keighley D G and Pickerill R K 1998 Mudstone-clastiform conglomerates and trough-shaped depressions from the Pennsylvanian lower Port Hood Formation of eastern
Canada: Occurrences due to soft-sediment deformation; J. Sedim. Res. 68 901-912.

Khan E A 1973 Discovery of fossil brachiopod of Cambrian affinity from Trans Aravalli Vindhyan sequence, near Jodhpur, Rajasthan; Seminar on Recent advances in the geology of Rajasthan and Gujarat; Abstract, pp. $74-75$.

Khilnani V B 1964 A note on the occurrence of algal stromatolites in the Vindhyan limestone from Bilara area, Jodhpur district, Rajasthan; Curr. Sci. 33(24) 750751.

Khilnani V B 1968 Stromatolites of Vindhyan Limestone, from Bilara, district Jodhpur, Rajasthan; Quart. J. Geol. Min. Met. Soc. India 40(1) 1-6.

Knoll A H and Carroll S B 1999 Early animal evolution: Emerging views from comparative biology and geology; Science 284(5423) 2129-2137.

Kumar S and Ahmad S 2012a Restudy of an Ediacaran medusoid Marsonia artiyansis from the Jodhpur Sandstone, Jodhpur district, western Rajasthan; J. Palaeontol. Soc. India 57(2) 135-142.

Kumar S and Ahmad S 2012b Five-armed body fossil from the Ediacaran Jodhpur Sandstone, Marwar Supergroup, western Rajasthan, India: A possible precursor of phylum Echinodermata; Curr. Sci. 102(1) 24-26.

Kumar S and Ahmad S 2014 Microbially induced sedimentary structures (MISS) from the Ediacaran Jodhpur Sandstone, Marwar Supergroup, western Rajasthan; J. Asian Earth Sci. 91 352-361.

Kumar S and Ahmad S 2016 Problematic structures from the Ediacaran Jodhpur Sandstone, Rajasthan, India and their possible affinity; J. Palaeontol. Soc. India 61(1) $63-73$.

Kumar S and Pandey S K 2008 Discovery of trilobite trace fossils from the Nagaur Sandstone, the Marwar Supergroup, Dulmera area, District Bikaner, Rajasthan; Curr. Sci. 94 1081-1085.

Kumar S and Pandey S K 2009 Note on the occurrence of Arumberia banksi and associated fossils from the Jodhpur Sandstone, Marwar Supergroup, western Rajasthan; J. Palaeontol. Soc. India 54(2) 171-178.

Kumar S and Pandey S K 2010 Trace fossils from the Nagaur Sandstone, Marwar Supergroup, Dulmera area, Bikaner district, Rajasthan, India; J. Asian Earth Sci. 38 77-85.

Kumar S, Misra P K and Pandey S K 2009 Ediacaran megaplant fossils with Voucheriacean affinity from the Jodhpur Sandstone, Marwar Supergroup, western Rajasthan; Curr. Sci. 97(5) 701-705.

Kumar V, Rastogi S P, Chandra R 2005 Geology and evolution of Nagaur-Ganganagar Basin with special reference to salt and potash mineralization; Spec. Publ. Series Geol. Surv. India 62 1-151.

Lamsdell J C, Stein M and Selden P A 2013 Kodymirus and the case for convergence of raptorial appendages in Cambrian arthropods; Naturwissenschaften $100811-$ 825.

Lucas S G, Minter N J, Spielmann J A, Hunt A P and Braddy S J 2005 Early Permian Ichnofossil assemblage from the Fra Cristobal Mountains, southern New Mexico; In: The Permian of Central New Mexico (eds) Lucas S G, Zeigler K E and Spielmann J, New Mexico Mus. Nat. Hist. Sci. Bull. 31 140-150. 
MacNaughton R B and Narbonne G M 1999 Evolution and ecology of Neoproterozoic-Lower Cambrian trace fossils, NW Canada; Palaios 14 97-115.

Maheshwari A, Sial A N and Mathur S C 2003 Carbon and oxygen isotope profiles from the terminal Pre-Cambrian Marwar Supergroup, Rajasthan, India; Carbonate Evaporite 18(1) 268-276.

Maithy P K 1984 Microbiota from stromatolite stratifera of Bilara Group (Marwar Supergroup, western Rajasthan); Palaeobotanist 32 82-85.

Maloof A C, Rose C V, Beach R, Samuels B M, Calmet C C, Erwin D H, Poirier G R, Yao N and Simons F J 2010 Possible animal-body fossils in pre-Marinoan limestones from South Australia; Nat. Geosci. 3 653-659.

Mángano M G and Buatois L A 2003 Trace fossils; In: Ordovician Fossils of Argentina (ed.) Benedetto J L, Universidad Nacional de Córdoba, Secretaría de Cienciay Tecnología, pp. 507-553.

Mángano M G, Buatois L A and Aceñolaza G F 1996 Trace fossils and sedimentary facies from an Early Ordovician tide-dominated shelf (Santa Rosita Formation, northwest Argentina): Implications for ichnofacies models of shallow marine successions; Ichnos 5 53-88.

Mángano M G, Buatois L A and Fernando M G 2005 Ichnology of the Alfarcito Member (Santa Rosita Formation) of north-western Argentina: Animal-substrate interactions in a lower Paleozoic wave-dominated shallow sea; Ameghiniana 42(4) 641-668.

Martin R E 1999 Taphonomy a process approach; Cambridge University Press, Cambridge, 508p.

Mazumdar A and Bhattacharya S K 2004 Stable isotopic study of late Neoproterozoic-early Cambrian (?) sediments from Nagaur-Ganganagar basin, western India: Possible signatures of global and regional C-isotope events; Geochem. J. 38 163-175.

Mazumdar A and Strauss H 2006 Sulfur and strontium isotopic compositions of carbonate and evaporate rocks from the Late Neoproterozoic-early Cambrian Bilara Group (Nagaur-Ganganagar Basin, India): Constrains on intrabasinal correlation and global sulfur cycle; Precamb. Res. $149217-230$.

McKenzie N R 2012 Integrated geochronologic, geochemical, and sedimentological investigation of Proterozoic Early Paleozoic Strata: From northern India to global perspectives (Ph.D. Thesis); University of California, Riverside, USA, 131p.

McKenzie N R, Hughes N C, Myrow P M, Xiao S and Sharma M 2011 Correlation of PrecambrianCambrian sedimentary successions across northern India and the utility of isotopic signatures of Himalayan lithotectonic zones; Earth Planet. Sci. Lett. 312 471483.

McMenamin M A S 1986 The Garden of Ediacara; Palaios 1 $178-182$.

Meert J G and Pandit M K 2015 The Archaean and Proterozoic history of Peninsular India: Tectonic framework for Precambrian sedimentary basins in India; In: Precambrian basins of India: Stratigraphic and tectonic context (eds) Mazumder R and Eriksson P G, Mem. Geol. Soc. London 43 29-54.

Meert J G, Pandit M K and Kamenov G D 2013 Further geochronological and paleomagnetic constraints on Malani (and pre-Malani) magmatism in NW India; Tectonophys. 608 1254-1267.

Mehrotra N C, Babu R, Tewari R, Jha N, Kumar P, Singh V K and Shukla M 2008 New global opportunities for hydrocarbon exploration in Neoproterozoic Basins of Indian subcontinent; J. Geol. Soc. India $72543-$ 546.

Mikuláš R 1995 Trace fossils from the Paseky Shale (Early Cambrian, Czech Republic); J. Czech Geol. Soc. 40 $37-45$.

Minter N J and Lucas S G 2009 The arthropod trace fossil Cruziana and associated Ichnotaxa from the Lower Permian Abo Formation, Socorro County, New Mexico; New Mexico Geol. Soc. Guidebook, 60th Field conference, Geology of the Chupadera Mesa Region, pp. 291298.

Paliwal B S 2007 Some fossil like structures in the rocks of the Marwar Supergroup, western Rajasthan, India; In: Emerging trends of research in Geology (north western India) (eds) Avidich $\mathrm{P} \mathrm{C}$ and Bhu $\mathrm{H}$, Department of Geology, Mohan Lal Sukhadia University, Udaipur, India, pp. $1-19$.

Pandey D K and Bahadur T 2009 A review of the stratigraphy of Marwar Supergroup of west-central Rajasthan; J. Geol. Soc. India 73 747-758.

Pandey D K, Uchman A, Kumar V and Shekhawat R S 2014 Cambrian trace fossils of the Cruziana ichnofacies from the Bikaner-Nagaur Basin, north western Indian Craton; J. Asian Earth Sci. 81 129-141.

Pandey S K and Sharma M 2017 Enigmatic Ediacaran megascopic bedding plane structures on the Sonia Sandstone, Jodhpur Group, Marwar Supergroup, India: Seaweed or problematica?; Geol. J. 52 784-807.

Pandit M K, Sial A N, Jamrani S S and Ferreira V P 2001 Carbon isotope profile across the Bilara Group rocks of Trans-Aravalli Marwar Supergroup in western India: Implications for Neoproterozoic-Cambrian transition; Gondwana Res. 4 387-394.

Parcha S K and Pandey S 2011 Ichnofossils and their significance in the Cambrian successions of the Parahio Valley in the Spiti Basin, Tethys Himalaya, India; J. Asian Earth Sci. 42 1097-1116.

Parcha S K and Singh B P 2010 Stratigraphic significance of the Cambrian Ichnofauna of the Zanskar Region, Ladakh Himalaya, India; J. Geol. Soc. India 75 503-517.

Pareek H S 1984 Pre-Quaternary geology and mineral resources of northwestern Rajasthan; Geol. Survey India Memoir 115 1-95.

Parihar V S, Gaur V and Nama S L 2012 Trace fossils and microbial mat-induced sedimentary structures from the Girbhakar Sandstone of Marwar Supergroup, Bhopalgarh area, Jodhpur, Rajasthan, India; J. Earth Sci. Climatic Change 12(2) 1-3.

Peng S, Babcock L E and Cooper R A 2012 The Cambrian Period; In: The Geological Time Scale 2012 (eds) Gradstein F, Ogg J, Schmitz M and Ogg G, Elsevier $1437-$ 488.

Poiré D G, Spalletti L A and Valle A D 2003 The Cambrian-Ordovician siliciclastic platform of the Balcarce Formation (Tandilia System, Argentina): Facies, trace fossils, palaeoenvironments and sequence stratigraphy; Geol. Acta 1(1) 41-60. 
Prasad B, Asher R and Borgohai B 2010 Late Neoproterozoic (Ediacaran)-Early Paleozoic (Cambrian) acritarchs from the Marwar Supergroup, Bikaner-Nagaur Basin, Rajasthan; J. Geol. Soc. India 75 415-431.

Raghav K S, De C and Jain R L 2005 The first record of Vendian Medusoids and trace fossils bearing algal mat grounds from the basal part of the Marwar Supergroup of Rajasthan, India; Indian Min. 59(1-2) 23-30.

Reineck H E and Singh I B 1980 Depositional Sedimentary Environments; Springer-Verlag: Berlin, 551p.

Samanta P, Mukhopadhyay S, Mandal A and Sarkar S 2011 Microbial mat structures in profile: The Neoproterozoic Sonia Sandstone, Rajasthan, India; J. Asian Earth Sci. 40 $542-549$.

Samanta P, Mukhopadhyay S, Sarkar S and Eriksson P G 2015 Neoproterozoic substrate condition vis-à-vis microbial mat structure and its implications: Sonia Sandstone, Rajasthan, India; J. Asian Earth Sci. 106 186196.

Sarkar S, Banerjee S, Eriksson P G and Catuneanu O 2005 Microbial mat control on siliciclastic Precambrian sequence stratigraphic architecture: Examples from India; Sedim. Geol. 176 195-209.

Sarkar S, Banerjee S, Samanta P, Chakraborty N, Chakraborty P P, Mukhopadhyay S and Singh A K 2014 Microbial mat records in siliciclastic rocks: Examples from Four Indian Proterozoic basins and their modern equivalents in Gulf of Cambay; J. Asian Earth Sci. 91 362-273.

Sarkar S, Bose P K, Samanta P, Sengupta P and Eriksson P G 2008 Microbial mat mediated structures in the Ediacaran Sonia Sandstone, Rajasthan, India, and their implications for Proterozoic sedimentation; Precamb. Res. $162248-263$.

Sarkar S, Samanta P, Mukhopadhyay S and Bose P K 2012 Stratigraphic architecture of the Sonia Fluvial interval, India in its Precambrian context; Precamb. Res. 214-215 $210-226$

Schopf J W, Kudryavtsev A B, Agresti D G, Czaja A D and Wdowiak T J 2005 Raman imagery: A new approach to assess the geochemical maturity and biogenicity of permineralized Precambrian fossils; Astrobiology 5 333371.

Seilacher A 1990 Paleozoic trace fossils; In: The geology of Egypt (ed.) Said R, Balkema A A, Rotterdam, pp. 649670.

Shah S K and Sudan C S 1983 Trace fossils from the Cambrian of Kashmir and their stratigraphic significance; $J$. Geol. Soc. India 24 194-202.

Sharma M and Pandey S K 2011 Fossil lagerstättens and an age assessment of the Nagaur Sandstone, Marwar Supergroup. XXIII Indian Colloquim on 'Micropalaeontology and Stratigraphy (ICMS) and International Symposium on Global Bioevents in the Earth History', XXIII ICMS$64,82$.

Sharma M and Shukla Y 2012 Mesoproterozoic carbonaceous fossils from the Neoproterozoic Bhima Basin, Karnataka, South India; Geol. Soc. London Spec. Publ. 366 277-293.

Sharma M, Ahmad S, Pandey S K and Kumar K 2018 Behavioral and taphonomical testimony of Treptichnus pedum, inferences from the Nagaur Sandstone, Marwar Supergroup, India; Bull. Geosci., https://doi.org/10.3140/bull. geosci.1666.
Shrivastava B P 1971 Rock stratigraphic nomenclature for the sedimentaries of west-central Rajasthan; Geol. Mining Metallur. Soc. India 44 1-19.

Shrivastava B P 2005 Introductory treatise on geology of sedimentary basins and oil, gas and lignite scenario of western Rajasthan; In: Proceedings of National Seminar on Oil, Gas and Lignite Scenario with Special Reference to Rajasthan (eds) Shrivastava B P and Mathur A, pp. 17-31.

Singh B P, Bhargava O N, Chaubey R S and Kishore N 2014 Echnology and depositional environment of the Cambrian Nagaur Sandstone (Nagaur Group) along the Dulmera section, Bikaner Nagaur Basin, Rajasthan; Acta Geol. SinEngl. 88(6) 1665-1680.

Singh B P, Bhargava O N, Kishore N, Ahluwalia A D and Chuabey R S 2013 Arthropod from the BikanerNagaur Basin, peninsular India; Curr. Sci. 104(6) 706707.

Singh B P, Bhargava O N, Sharma C A, Chaubey R S, Prasad S K, Negi R S and Kishore N 2017 Treptichnus Ichnogenus from the Cambrian of India and Bhutan: Its relevance to the Precambrian-Cambrian boundary; $J$. Paleontol. Soc. India 62(1) 39-50.

Singh I B and Rai V 1983 Fauna and biogenic structures in Krol-Tal succession (Vendian-Early Cambrian) Lesser Himalaya: Their biostratigraphic and palaeoecological signature; J. Palaeontol. Soc. India $2867-$ 90.

Srikantan B, Sant V N and Sharma S B 1969 Geology and preliminary assessment of Birmania phosphate deposit, Jaisalmer District, Rajasthan; J. Mines Metals Fuels $\mathbf{1 7}$ 107-113.

Srivastava P 2012a Treptichnus pedum: An ichnofossil representing Ediacaran-Cambrian Boundary in the Nagaur Group, the Marwar Supergroup, Rajasthan, India; Proc. Indian Natl. Sci. Acad. 78 161-169.

Srivastava P 2012b Problematic worms and Priapulid-like fossils from the Nagaur Group, the Marwar Supergroup, India; Ichnos 19(3) 156-164.

Srivastava P 2012c Ediacaran discs from the Jodhpur Sandstone, Marwar Supergroup, India: A biological diversification or taphonomic interplay?; Int. J. Geosci. $\mathbf{3}$ 1120-1126.

Srivastava P 2014 Largest Ediacaran discs from the Jodhpur Sandstone, Marwar Supergroup, India: Their palaeobiological significance; Geosci. Front. 5(2) 183-191.

Sudan C S and Sharma U K 2000 Trace fossils distribution and stratigraphy setting of Garbyang Formation in the Girthi-Ganga section of Kumaun; J. Geol. Soc. India 55(2) 175-182.

Sudan C S and Sharma U K 2001 Trace fossils from the Cambrian rocks of the Kunzum La Section, Spiti, H.P., India; J. Paleontol. Soc. India 46 161-171.

Tiwari M and Parcha S K 2006 Early Cambrian trace fossils from the Tal Formation of the Mussoorie Syncline, India; Curr. Sci. 90(1) 113-118.

Tiwari M, Parcha S K, Shukla R and Joshi H 2013 Ichnology of the Early Cambrian Tal Group, Mussoorie Syncline, Lesser Himalaya, India; J. Earth Syst. Sci. 122(6) $1467-$ 1475 .

Torsvik T H, Carter L M, Ashwal L D, Bhushan S K, Pandit M K and Jamtyveit B 2001 Rodinia refined or obscured: 
Paleomagnetism of the Malani Igneous Suite (NW India); Precamb. Res. 108 319-333.

Uchman A, Drygant D, Paszkowski M, Porȩbski J S and Turnau E 2004 Early Devonian trace fossils in nonmarine redbeds in Podolia, Ukraine: Palaeoenvironmental Implications; Palaeogeogr. Palaeoclimatol. Palaeocol. 214 67-83.

van Lente B, Ashwal L D, Pandit M K, Bowring S A and Torsvik T H 2009 Neoproterozoic hydrothermallyaltered basaltic rocks from Rajasthan, northwest India: Implications for late Precambrian tectonic evolution of the Aravalli Craton; Precamb. Res. 170 202222.

Wang Y 2007 Arthropods tracks in Kaili ichnocoenosis from Lower-Middle Cambrian Kaili Formation in Jianhe County, Guizhou Province, China; Geol. Rev. 53(4) 731751.

Corresponding editor: Pratul K SARAswati
Wang Y, Zhang H J, Yang X G, Li S L and Wang Q S 2006 Trace fossils from the Middle Cambrian Jialao Formation at Nangao Town, Danzhai County, Guizhou Province, China; Geol. Bull. China 25 475-481.

Weiguo S, Xiang W G and Benhe Z 1986 Macroscopic wormlike body fossils from the Upper Precambrian 900-700 Ma Huainan district, Anhui, China and their stratigraphic and evolutionary significance; Precambrian Res. 31 377403.

Yang Shi-pu and Wang Xun-chang 1991 Middle Cambrian Hsuchuangian trace fossils from southern north China platform and their sedimentological significance; Acta Palaeontol. Sin. 30(1) 74-89.

Yang Shi-pu, Changming $\mathrm{Hu}$ and Sun Yongchuan 1987 Discovery of Late Devonian trace fossils from Guodjngshan district, Hanyang, China and its significance; Earth Sci. 12(1) 1-8. 